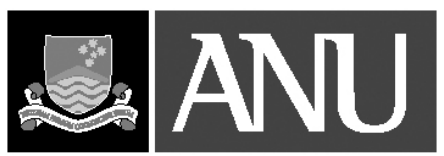

THE AUSTRALIAN NATIONAL UNIVERSITY

AUSTRALIA-JAPAN RESEARCH CENTRE

ANU COLLEGE OF ASIA \& THE PACIFIC

CRAWFORD SCHOOL OF ECONOMICS AND GOVERNMENT

\title{
JAPANESE FDI IN CHINA: DETERMINANTS AND PERFORMANCE
}

Shiro Armstrong

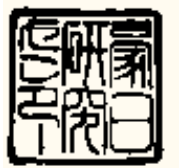

ASIA PACIFIC ECONOMIC PAPERS

No. 378, 2009 



\title{
ASIA PACIFIC ECONOMIC PAPER NO. 378
}

\author{
2009
}

\section{Japanese FDI in China: determinants and performance}

Shiro Armstrong

Crawford School of Economics and Government, Australian National University

AUSTRALIA-JAPAN RESEARCH CENTRE CRAWFORD SCHOOL OF ECONOMICS \& GOVERNMENT

ANU COLLEGE OF ASIA AND THE PACIFIC 
This work is copyright. Apart from those uses which may be permitted under the Copyright Act 1968 as amended, no part may be reproduced by any process without written permission.

Asia Pacific Economic Papers are published under the direction of the Editorial Committee of the Australia-Japan Research Centre (AJRC). Members of the Editorial Committee are:

Professor Jenny Corbett

Executive Director

Australia-Japan Research Centre

The Australian National University, Canberra

Professor Emeritus Peter Drysdale

Crawford School of Economics and Government

The Australian National University, Canberra

Professor Christopher Findlay

Professor of Economics

University of Adelaide

Adelaide, South Australia

Professor Stuart Harris

Department of International Relations

The Australian National University, Canberra

Dr Kazuki Onji

Crawford School of Economics and Government

The Australian National University, Canberra

Papers submitted for publication in this series are subject to double-blind external review by two referees. The views expressed in APEPs are those of the individual authors and do not represent the views of the Australia-Japan Research Centre, the Crawford School, or the institutions to which authors are attached.

The Australia-Japan Research Centre is part of the Crawford School of Economics and Government, The Australian National University, Canberra.

ISSN 07288409

ISBN 0864133324

Australia-Japan Research Centre

Crawford School of Economics and Government

The Australian National University

CANBerra ACT 0200

Telephone: $(612) 61253780$

FACsimile: (61 2) 61250767

E-MAIL:AJRC@ANU.EDU.AU

URL: HTTP://WWW.CRAWFORD.ANU.EDU.AU 


\title{
JAPANESE FDI IN CHINA: DETERMINANTS AND PERFORMANCE*
}

\begin{abstract}
Japanese foreign direct investment (FDI) into China is analysed using an FDI model that accounts for different modes of FDI as well as third country effects and adds to existing literature by incorporating a new measurement of political distance. Political closeness between countries is shown to affect FDI. An improvement in political relations is associated with an increase in FDI by reducing uncertainty in the investment environment. The performance of Japanese FDI into China is shown to be high relative to its potential since the late 1980s. The signing of the bilateral investment treaty in 1988 and China's WTO accession in 2001 were events that helped reduce uncertainty in bilateral investment, with the latter mitigating the effects of increased uncertainty from rising bilateral political tensions after 2001 .
\end{abstract}

This article was the runner-up for the AJRC's Crawford Award for 2008

\section{Introduction}

Foreign direct investment (FDI) is one of the most important dimensions in the economic relationship between Japan and China. China's economic rise has been achieved in large part due to its openness to the rest of the world, and importantly through its policies to attract foreign firm participation, first in production for export and later in its domestic economy. At the same time, Japanese multinational enterprises (MNEs) in key manufacturing industries such as electronics have been able to stay competitive by moving much of their production to China and the rest of East Asia.

FDI flows from one country to another face barriers and resistances. The analysis of barriers and resistances is much more prevalent in studies that model the flow of goods than those that model the flow of FDI. The case of trade is reviewed in a study by Anderson and van Wincoop (2004) where trade over a border is estimated to face resistances equivalent to a 170 per cent tariff. The economic distance between two countries can be represented by the cost of getting investment flows to another country. On average, FDI will flow to countries with close economic distance, not necessarily geographic distance, as they face less barriers to investment. Economic distances vary due to the ease or resistance to capital flows between countries. Some of the key characteristics of economic and political distance are discussed below. 
This study measures the resistances to FDI flows by combining two important streams of literature which have sought to analyse foreign direct investment (FDI) relationships, both of which have developed almost exclusively of each other without any significant overlap. One is the international business or global strategy literature that concerns itself with cultural differences, institutional differences and the choice of mode of entry of MNEs given uncertainty caused by those and other resistances (Hymer 1960; Kogut and Singh 1988; Ghemawat 2007). The other is younger and less established than the international business or international trade literature and is concerned with modelling MNE activity with such factors as country resource endowment differences reflecting comparative advantage, spatial effects in a multilateral sense and also scale of economies (Helpman 1984; Markusen 1984; Carr et al. 2001; Markusen 2002; Egger and Pfaffermayr 2004; Davies 2008).

Combining analysis of both strands of FDI literature would seem to allow modelling consistent with theoretical derivations based on spatial linkages and different modes of FDI, with accounting for resistances similar to those that receive much more focus in the international business literature (see Ghemawat 2007).

This study also includes a measurement of political distance as part of the analysis and estimation of FDI. Political distance is a measure of how 'close' two countries are politically, or geopolitically and how well they get along. Two countries who are political and security allies can be described as being close in terms of political distance, whereas two nations that are political rivals, perhaps in the extreme, can be described as politically distant. Political distance is a potentially important factor in affecting intangible resistances, as bilateral political tensions can erode confidence in the investment environment and increase uncertainty.

The purpose of this study is twofold. First, it measures the performance of Japanese FDI into China by obtaining a measure of all resistances to investment flows. This is done by measuring the determinants of FDI according to the most theoretically consistent and best performing model for FDI, which accounts for third country, or multilateral effects, to estimate what potential Japanese FDI flows into China might be. The estimation of determinants allows for the measurement of a counterfactual amount of FDI. The results are compared to overall Japanese outward FDI as well as FDI into China from the United States and Europe, the other main sources of China's FDI. As the model already controls for third-country effects, the results can estimate the resistance to investment flows after accounting for investment diversion. Second, it seeks to measure the influence of political factors on flows of investment worldwide with a focus on the relationship between Japan and China. The inclusion of a political relationship variable allows for a measurement of the impact of changes in uncertainty in the bilateral investment climate. 
The paper is organised as follows. The first section is an explanation of hypothesised resistances to FDI and how these might affect FDI. Then the theoretical models of FDI are reviewed before the model and data for this study are explained in detail. This is followed by discussion of results. The FDI modelling allows comparisons against counterfactual FDI levels which are discussed for both Japanese outward FDI as well as Chinese inward FDI. Finally, a model with political distance is incorporated and explained before a final section which concludes.

\section{Distance in FDI}

FDI between countries faces resistances. These resistances contribute to the economic distance between economically linked countries where economic distance can be thought of as the transit cost of capital flows. FDI flows often face different resistances over similar geographic distances necessitating a measurement of those resistances and the effects on the scale and structure of FDI.

The concept of resistances is used widely in trade literature, often called trade frictions or psychic distance (Beckerman 1956; Linnemann 1966; Drysdale and Garnaut 1982). Resistances can include easy-to-measure, explicit trade or investment barriers and geographic distance as well as those factors that inhibit or promote investment flows that are difficult to measure such as uncertainty, asymmetric information and hidden costs.

The MNE international business literature focuses on differences between countries and the implications for the modes of entry into markets by MNEs. Resistances have a significant impact on the scale and structure of FDI (Ghemawat 2007).

Guiso et al. (2004) find that a measure of trust and a measure of cultural similarity, the latter determined by religion, history of conflicts and genetic similarities, affect economic linkages in European countries, including FDI. They recognise that these are separate from tangible resistances which can be measured more objectively.

The role of resistance to FDI is also investigated by Erramilli and D'Souza (1995) who use the term cultural distance to describe the uncertainty that a firm faces in investing in another country. They separate uncertainties into internal and external uncertainty, where internal uncertainty is related to a firm's uncertainty about the potential host market and external uncertainty is volatility in the host market itself and is unrelated, or external, to the home country of the firm deciding to invest. Their results suggest that increases in either type of uncertainty increase resistances but in different ways and with different implications. An increase in internal uncertainty will increase what they term cultural distance and could lead to a decision to trade instead of invest. Trading does not commit as many resources as directly setting up a plant in a foreign country and is 
therefore hypothesised to be less sensitive to increases in uncertainty. This result hinges on an assumption that the FDI would be horizontal in nature and aimed at servicing the domestic market.

The separation of uncertainty into factors associated with an increase in uncertainty relating to that market or country, and those that apply to a specific firm or source country is important. An increase in political distance between Japan and China, which increases uncertainty and therefore resistance, is an internal risk according to the characterisation of Erramilli and D'Souza (1995) that should only affect Japanese firms but not other sources of FDI. Their findings do not automatically carry the implication that Japanese firms will substitute trade for FDI as Japanese FDI, like other FDI into China, is not solely horizontal FDI aimed at market share. Vertical and knowledge-based FDI have different determinants from horizontal FDI (Carr et al. 2001) and the response may be less elastic to host market changes. Determining the specific form of FDI would be difficult as FDI modes can vary within the same industry and even within the same firm. Also, isolating different shocks (those that affect internal and external uncertainty) on different kinds of FDI is difficult. This paper instead will compare Japanese FDI into China with FDI from the other main source countries over a period involving shocks of both kinds. The aim here is to measure economic distance in FDI and to measure the effects of increased uncertainty that is specific to a bilateral relationship (internal uncertainty) as well as uncertainty that is country specific (external uncertainty).

Political distance is one measure of internal uncertainty. A bilateral measure of political distance has not been included in any cross-country analysis of FDI flows, but a measure of host country domestic political risk has been included in studies such as Baltagi et al. (2007). The interaction between trade and a measure of political distance has a rich literature (See Polachek 1980; Pollins 1989a; Pollins 1989b; Polachek 1997; Reuveny and Kang 2003). This study attempts to fill the void in the literature and includes the influence of political distance on FDI.

\section{FDI models}

Models that seek to explain FDI flows are not as widely used as, and do not have the theoretical underpinnings of, the gravity model of trade, reflecting in part the only recent rise in the importance of FDI in the analysis of international economic relations. The link between FDI and trade has led to a rush of studies using traditional gravity variables of economic size and distance to explain FDI flows. Recent research suggests, however, that FDI is better explained when differences in modes of FDI are taken into account (Egger and Pfaffermyer 2004; Blonigen 2005). 
The earlier general equilibrium models of FDI by Markusen (1984) and Helpman (1984) set the foundations for the current understanding of MNE behaviour. Markusen developed a model of horizontal FDI where MNEs produce offshore from the country of their headquarters to avoid trade costs such as transportation and tariffs. This form of FDI can be characterised as market-seeking FDI, where a firm will set up a plant to produce and sell in that host market. This development in the literature came concurrently with Helpman's model of vertical FDI where MNEs take advantage of different factor prices across countries to cut production costs. Simply put, vertical FDI is trade-increasing and horizontal FDI is trade-reducing.

Recognition of the existence of a combination of both vertical and horizontal types of FDI within MNEs led to later studies combining the two models into a knowledge capital (or knowledge-based) model of FDI (Carr et al. 2001; Markusen 2002; Markusen and Maskus 2002). Knowledge capital models describe FDI operations where the research and development, as well as other skilled-labour-intensive, or knowledge-intensive activities, are geographically separated from production (Carr et al. 2001). The separation of such activities in general means that knowledge-based activities can be supplied at low cost to numerous production locations (Carr et al. 2001). These models made significant steps towards understanding MNE behaviour but were general equilibrium models in a simple two-country framework and therefore not adequate in explaining or characterising MNEs which made their FDI decisions based not only on home and host-country characteristics, but also on other-country characteristics.

The inclusion of spatial effects, or third-country effects, is similar to developments in the gravity model of trade that recognise that trade is occurring in a many-country world. Multilateral effects have become commonplace in gravity models since the seminal paper by Anderson and van Wincoop (2003). The empirical work in FDI studies, which take account of spatial effects and FDI patterns beyond the horizontal and vertical types of FDI, confirms the importance of taking account of third-country effects.

The strong interdependencies between trade and investment led to many studies where FDI was modelled using gravity model determinants of trade, and these models were relatively successful at explaining FDI (see, for example, Brenton and Di Mauro 1999; Razin et al. 2002; and Eichengreen and Tong 2005). However, as Blonigen and Davies (2000) show, the knowledge capital models of FDI consistently explain FDI better than the gravity model of trade determinants. Blonigen (2005) details the determinants of FDI, based on a survey of empirical studies, which are different from the determinants of trade. Differences in factor endowments and hence comparative advantages determine not just the amount of FDI as it would for trade flows, but the mode of FDI, depending on the abundant factor. 
Theoretical derivations of models which estimate FDI are based on firm decisions where the choice to trade or invest is endogenous and depends on economies of scale, factor prices, country risk and transportation costs (Dee 2007).

The model used in Baltagi et al. (2007) allows for four types of FDI: vertical, horizontal, export platform and complex vertical. The last two, export platform and complex vertical, are knowledge-capital type FDI which include third-country effects. MNEs have increasingly employed an export platform model, or complex horizontal model, of FDI where a production plant is set up in a low cost country solely for the purpose of exporting to nearby markets. This form of FDI is apparent in East Asia where production networks dominate trade and investment. The complex vertical model of FDI represents a pattern of production where plants are set up in two countries offshore and the goods are traded back to the country that was the source of the FDI.

Consistent with Baltagi et al. (2007) and Dee (2007), the parent company country is denoted $\mathrm{d}$, the host country of the investment is denoted $\mathrm{i}$ and the third market is denoted $\mathrm{j}$.

Dee (2007) illustrates the four patterns of FDI:

Horizontal: $\quad$ plants in $d$ and $i$, exports from $d$ to $j$

Export platform: $\quad$ plants in $d$ and $i$, exports from $i$ to $j$

Vertical: $\quad$ plants in $i$ and $j$, exports from $i$ to $d$

Complex vertical: $\quad$ plants in $i$ and $j$, exports from $j$ to $d$

Many studies model a two factor world, some with skilled and unskilled labour (see for example Davies (2008)) and others with capital and labour. Results found in studies such as Egger and Pfaffermayer (2004), Baltagi et al. (2007) and Dee (2007) show that a three- factor world with skilled labour (or human capital), unskilled labour and physical capital, gives a better explanation of FDI flows.

The literature on MNE behaviour and FDI models has shown the importance of including scale, distance, relative factor endowments, the interdependencies between markets and networks of production (multilateral effects). A measurement of risk is included in Baltagi et al. (2007) without theoretical justification. The inclusion is justified as it relates to the empirical evidence of uncertainty increasing in one country and affecting all FDI to that country. The increase in uncertainty increases resistance. The measure of risk which is included in other studies is not bilateral relationship specific and therefore can be thought of as a measure of external uncertainty - involving risk external to a bilateral relationship. 


\section{Model and data}

The model used in this study follows closely that of Dee (2007) which is based on Baltagi et al. (2007).

$\mathbf{F}_{\mathrm{t}}=\beta_{0}+\beta_{1}$ dis $+\beta_{2} \mathbf{G}_{\mathrm{t}}+\beta_{3} \mathbf{S}_{\mathrm{t}}+\beta_{4} \mathbf{k}_{\mathrm{t}}+\beta_{5} \mathbf{h}_{\mathrm{t}}+\beta_{6} \mathrm{l}_{\mathrm{t}}+\beta_{7} \Gamma_{\mathrm{t}}+\beta_{8} \Theta_{\mathrm{t}}+\beta_{9} \mathbf{R}_{\mathrm{t}}+\beta_{10} \mathbf{F T A}_{\mathrm{t}}$

$+\beta_{11} \mathbf{W G}_{\mathrm{t}}+\beta_{12} \mathbf{W S}_{\mathrm{t}}+\beta_{13} \mathbf{W k}_{\mathrm{t}}+\beta_{14} \mathbf{W h}_{\mathrm{t}}+\beta_{15} \mathbf{W l}_{\mathrm{t}}+\beta_{16} \mathbf{W} \Gamma_{\mathrm{t}}+\beta_{17} \mathbf{W \Theta}_{\mathrm{t}}$

$+\beta_{18} \mathbf{W R}_{\mathrm{t}}+\beta_{19} \mathbf{W F T A}_{\mathrm{t}}+\mathbf{u}_{\mathrm{t}}$

Where

$\mathrm{F}_{\mathrm{t}}$ is the log of FDI (both stock and flows are used)

dis is the log of the great circle distance between capital cities of $d$ and $i$.

$\mathbf{G}_{\mathrm{t}}$ is the $\log$ of the sum of country $d$ and country $i$ GDPs: $\ln \left(\mathrm{GDP}_{\mathrm{d}}+\mathrm{GDP}_{\mathrm{i}}\right)$

$\mathrm{S}_{\mathrm{t}}$ is a measure of GDP similarity: $\left(1-\mathrm{s}_{\mathrm{d}}{ }^{2}-\mathrm{s}_{\mathrm{i}}^{2}\right)$

where $s_{\mathrm{d}}=\mathrm{GDP}_{\mathrm{d}} /\left(\mathrm{GDP}_{\mathrm{d}}+\mathrm{GDP}_{\mathrm{i}}\right)$ and $\mathrm{s}_{\mathrm{i}}=\mathrm{GDP}_{\mathrm{i}} /\left(\mathrm{GDP}_{\mathrm{d}}+\mathrm{GDP}_{\mathrm{i}}\right)$

$\mathbf{k}_{\mathrm{t}}$ is the $\log$ of the ratio of source country to destination country capital stock: $\ln \left(\mathrm{K}_{\mathrm{d}} /\right.$ $\mathrm{K}_{\mathrm{i}}$ )

$\mathbf{h}_{\mathrm{t}}$ is the $\log$ of the ratio of source country to destination country human capital: $\ln \left(\mathrm{H}_{\mathrm{d}} /\right.$ $\mathrm{H}_{\mathrm{i}}$ )

$1_{t}$ is the log of the ratio of source country to destination country unskilled labour: $\ln \left(\mathrm{L}_{\mathrm{d}} /\right.$

$\mathrm{L}_{\mathrm{i}}$ )

$\Gamma_{t}$ is an interaction term between $\mathbf{G}_{\mathrm{t}}$ and $\mathbf{k}_{\mathrm{t}}: \mathbf{G}_{\mathrm{t}} \mathbf{k}_{\mathrm{t}}$

$\Theta_{t}$ is an interaction term between distance and the difference in capital and labour ratios:

$$
\operatorname{dis}\left(k_{t}-1_{t}\right)
$$

$\mathbf{R}_{\mathrm{t}}$ is a measure of risk in the FDI recipient country

FTA $_{t}$ is a variable that takes the value of one if country $d$ and $i$ have a free trade agreement in force in year $\mathrm{t}$.

$\mathbf{W}$ is a measure of multilateral effects interacted with each term. $\mathbf{W G}_{t}$, for example, is the inverse distance weighted average of $\mathbf{G}_{t}$ between the source country and all third country markets.

The initial analysis will measure performance, defined as the actual amount of FDI relative to what the determinants predict. Those FDI relationships between source and host countries that perform well have lower resistances compared to those that do not perform well which are considered to face higher resistances. The second stage of the analysis includes measure of political distance and an inverse distance weighted average 
measure of political distance to explain some of the resistances that are difficult to measure. The measure of political distance is included explicitly as it is an important part of the Japan-China relationship (Armstrong 2007). The bilateral political distance variable is limited to the sub-period of 1990-2004.

The model follows Dee (2007) in its treatment of potentially spatially correlated error terms deterministically with the inclusion of an FTA variable and a weighted FTA variable. Baltagi et al. (2007) use the Gauss-Markov estimator to control for spatially correlated error terms. Baltagi et al. do not include a distance variable in their model, as is done here in Model 1 , because they control for distance in the spatially correlated error term.

FDI source countries are the United States, Japan, Canada, Germany, France, the United Kingdom and the Netherlands comprising seven of the largest eight FDI sources globally. ${ }^{1}$ There are ninety recipient countries used and they are listed in the data annex. Both FDI stocks and flows were used and FDI data are from OECD which has FDI data reported by OECD countries to OECD and non-OECD member countries. The panel is highly unbalanced from 1982 to 2006. Dummy variables for time are included and results controlling for both unobserved country-specific effects and country-pair effects are calculated and discussed.

GDP at purchasing power parity is used and is taken from the World Development Indicators along with labour force and gross fixed capital formation data. Capital stock is calculated from the perpetual inventory method from Leamer (1984) and explained in the data annex. The human capital data, from the International Labour Organisation and various national statistical agencies, is the absolute number of graduates from tertiary institutions, such as universities, in that country. The sum of the unskilled labour population and the population with a tertiary qualification is equal to the total labour force.

Table 1 is from Baltagi et al. (2007) and shows the hypothesised signs of coefficients based on the theoretical model developed in Egger and Pfaffermayr (2004) and extended in Baltagi et al. (2007).

The measure of risk introduced in Baltagi et al. is not found to be statistically significant in explaining FDI stocks or foreign affiliate sales in their model but the same variable is significant in Dee (2007). In this study, the Economic Freedom Index of the Fraser Institute ${ }^{2}$ is used and is expected to have a positive effect on FDI. The risk variable used by Baltagi et al. and Dee had a negative coefficient. Sensitivity tests are conducted using the Transparency International Corruption Perceptions Index ${ }^{3}$ and the World Bank Worldwide Governance Indicators ${ }^{4}$ with the assumption that all three variables are indicators of country risk. These country-specific risk variables all affect external uncertainty and are external to (not exclusive to) bilateral relationships. An increase in the measure of host country risk will affect all source country FDI. 
Table 1 Hypothesised signs of variable coefficients in FDI model

\begin{tabular}{l}
$\begin{array}{c}\text { Explanatory variable } \\
\text { Horizontal }\end{array}$ \\
\hline Bilateral size of $\mathrm{d}+\mathrm{i}$ \\
Similarity in size $(\mathrm{d}, \mathrm{i})$ \\
Capital ratio $(\mathrm{Kd} / \mathrm{Ki})$ \\
Human $\mathrm{K}$ ratio $(\mathrm{Hd} / \mathrm{Hi})$ \\
Labour ratio $(\mathrm{Ld} / \mathrm{Li})$ \\
Bilateral size* $\mathrm{Kd} / \mathrm{Ki}$ \\
$(\mathrm{Kd} / \mathrm{Ld}) /(\mathrm{Ki} / \mathrm{Li})^{*} \mathrm{t}$
\end{tabular}

Mode of FDI Export-platform

Vertical Complex vertical

Multilateral effects

Bilateral size of $d+j$

Similarity in size $(d, j)$

Capital ratio $(\mathrm{Kd} / \mathrm{Kj})$

Human K ratio $(\mathrm{Hd} / \mathrm{Hj})$

Labour ratio $(\mathrm{Ld} / \mathrm{Lj})$

Bilateral size ${ }^{*} \mathrm{Kd} / \mathrm{Kj}$

$(\mathrm{Kd} / \mathrm{Ld}) /(\mathrm{Kj} / \mathrm{Lj})^{*} \mathrm{t}$

$\begin{array}{rrrr}+ & + & + & + \\ +- & + & -1+ & +- \\ + & + & + & + \\ + & + & + & + \\ - & - & - & - \\ + & + & - & +-\end{array}$

Source: Baltagi et al. (2007).

\section{Results}

The results for estimating FDI stock are presented in Table 2. There are two models estimated with both country-specific effects and country-pair effects, both controlling for fixed effects.

Most variables are statistically significant at a high degree of significance in explaining FDI stock. The similar Baltagi et al. (2007) specification and even closer specification of Dee (2007) did not have as many variables with statistical significance as do the results in Table 2. As was the case in Baltagi et al. (2007) the multilateral variables (those weighted by inverse distance) are jointly significant, confirming their importance in explaining FDI.

The unbalanced panel was tested for auto-correlation using the method described in Arellano and Bond (1991), and the existence of auto-correlation was rejected. A Hausman test rejected the random effects specification over the fixed effects specification in all cases. The discussion that follows in the next section is based on the fixed effects results.

FTAs between source and destination countries have a positive and significant effect on FDI. The negative sign of the inverse-distance-weighted FTA variable, WFTA, in the results controlling for country-pair effects means that FTAs between source, $d$, and third countries, $j$ 's, reduce FDI from the source country to the destination country $\mathrm{i}$ but this variable is not statistically significant in this study. Investment diversion is not 
found for FDI flows in Table 3. Dee (2007) found that investment provisions in FTAs and other agreements did not impact on FDI patterns in the Asia Pacific region and her finding is inconsistent with the findings in this study. The destination countries are not aggregated into regions and detailed investment provisions in FTAs are not included as in Dee (2007) so that these agreements are not directly comparable.

Results for FDI flows are similar to those of FDI stock estimation and are presented in Table 3. The number of observations is less for FDI flows than FDI stock as the FDI data in the OECD data set was sparser for flows. The results are included to show the similarities in variable significance and consistency between stock and flow variables. FDI stock data are used in Baltagi et al. (2007) and Dee (2007) as is common in modelling FDI activity. The results from Table 2 will be the focus of the rest of the study.

In Table 2 distance is negative and highly significant. Baltagi et al. (2007) do not include distance as they are controlling for it in the second stage regression on spatially correlated error terms. Their inclusion here explicitly confirms previous empirical studies that distance matters. Bilateral economic size and similarity of GDPs are positive and significant, lending support to horizontal models of FDI (Markusen 1984). Scale is a significant explanator of FDI.

The GDP and capital ratio interaction term is negative when the country-specific fixed effects are controlled for and positive when the country-pair fixed effects are controlled for. In the first case, the positive impact diminishes with market size consistent with vertical FDI (Baltagi et al. 2007). When controlling country-pair unobservable characteristics, the mode of FDI is less obvious. 
No. 378, 2009

Table 2 Outward FDI stock: model estimation results

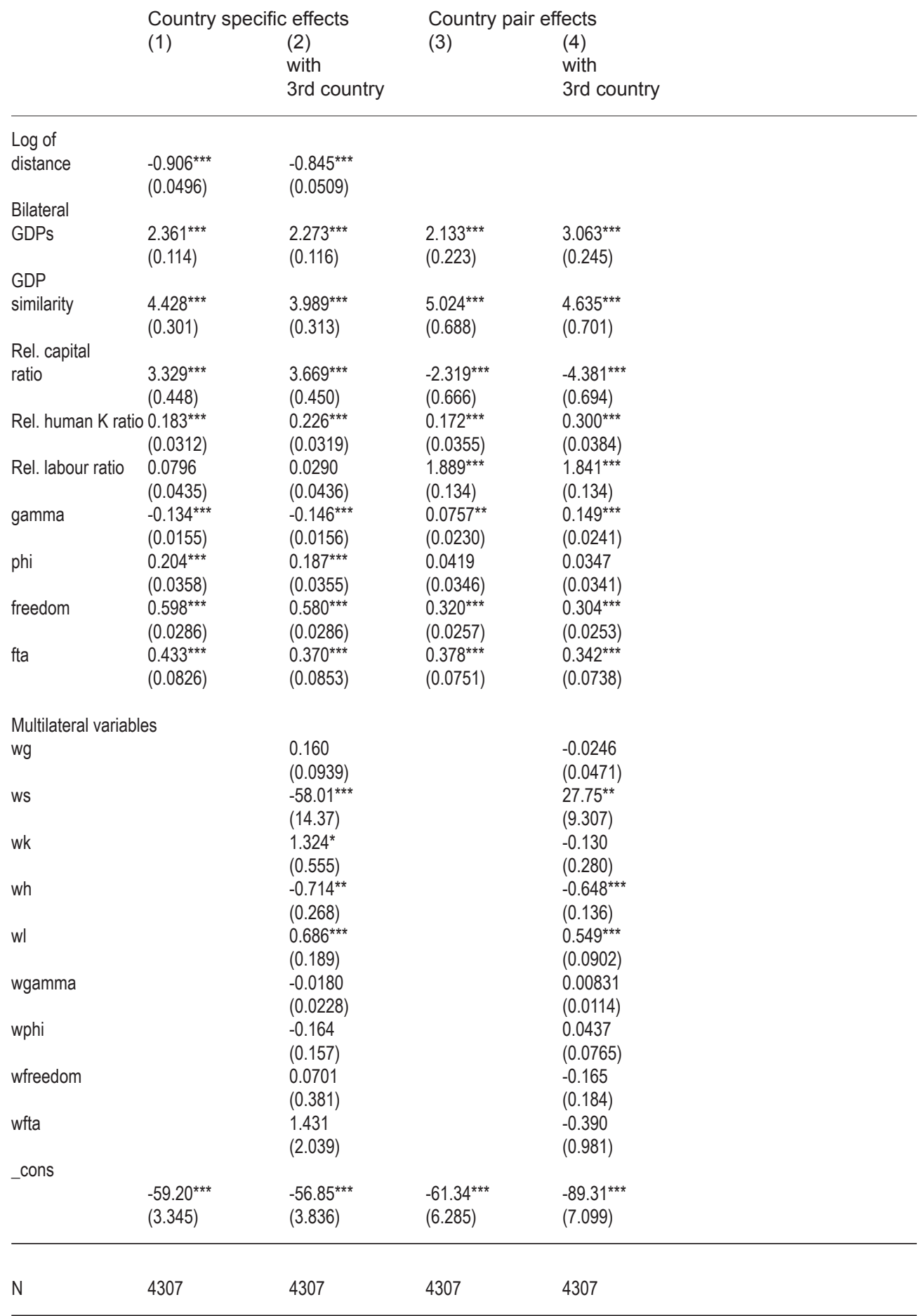

Note: Standard errors are in parentheses. ${ }^{*},{ }^{*}$ and ${ }^{* * *}$ indicate significance at the five per cent level, one per cent and 0.1 per cent levels, respectively. 
The source-to-destination fixed capital ratio is significant across all models but has a positive effect when country-specific fixed effects are controlled for and a negative effect when country-pair effects are controlled for. A positive and statistically significant effect of the capital ratio is what is expected for all modes of FDI according to the theoretical hypothesised signs in Table 1 . The negative and statistically significant results for country- pair effects are not consistent with theoretical priors but the results of Baltagi et al. (2007) are only statistically significant in two of their eight estimated models. The relative capital stock between source and destination countries is not a reliable indicator of the mode of FDI as the sign does not inform or distinguish between FDI modes although the statistical significance shows that it is important to control for.

The human capital ratio between source and destination is positive and statistically significant which is consistent with all four modes of FDI. The unskilled labour ratio is not statistically significant in most of the model specifications estimated. This result is surprising as it indicates unskilled labour ratios are not a significant explanatory factor in FDI. FDI from countries with low endowments of unskilled labour, such as Japan, is not aimed at countries with abundance of low-skilled labour once all else is controlled for. The result is consistent with Baltagi et al. (2007). However, the spatially weighted unskilled labour variable is statistically significant and has a positive effect across all specifications (FDI stocks as well as flows) consistent with modes of horizontal FDI and vertical FDI but not knowledge-capital FDI (Table 1). This may be a result of the length of the time period considered which dates back to 1982, before MNEs had complex network behaviour in their FDI and trade patterns. A substantial period after 1982, up to the latest data available, 2006, was covered and the statistical significance of the other spatially weighted variables and the joint significance for all spatially weighted variables is evidence of complex FDI.

Estimations are conducted using indexes of governance and corruption instead of economic freedom to test the sensitivity of the variables that proxy for risk. Another sensitivity test that is conducted is for the strict functional form assumption, taking the $\log$ of the sum of both GDPs. In the theoretical derivations of Markusen (2002), Carr et al. (2001) and Baltagi et al. (2007), there is a consensus that the sum of source and destination GDPs are a determinant of FDI but a log-linear form is taken in most models for ease of estimation. Table Al in the Appendix shows the result of sensitivity tests where GDPd and GDPi are included separately, and governance and corruption are substituted for economic freedom. The results show that relaxing the functional form of the GDP measures does not change the results significantly. This means that the ability to estimate the effects of host- and source-country GDP (and, indeed, third-country GDP) separately could give more flexibility in estimating and explaining the determinants of FDI. The statistical significance of both the corruption and governance measures, and comparable results for other variables, show the model is not particularly sensitive to the kind of measure used for risk. This is not surprising, as Baltagi et al. (2007) include 'a measure of risk' as an afterthought in their model derivation and could have just as easily included a measure of economic freedom or governance. 
No. 378, 2009

Table 3 Outward FDI flows: model estimation results

Country specific effects

(1)
(2)

with 3rd country
(3)

\begin{tabular}{|c|c|c|c|c|}
\hline Log of distance & $\begin{array}{c}-0.906^{* \star *} \\
(0.0496)\end{array}$ & $\begin{array}{l}-0.845^{\star \star *} \\
(0.0509)\end{array}$ & & \\
\hline Bilateral GDPs & $\begin{array}{l}2.361^{* * *} \\
(0.114)\end{array}$ & $\begin{array}{l}2.273^{\star \star \star} \\
(0.116)\end{array}$ & $\begin{array}{l}2.133^{\star * *} \\
(0.223)\end{array}$ & $\begin{array}{l}3.063^{* * *} \\
(0.245)\end{array}$ \\
\hline GDP similarity & $\begin{array}{l}4.428^{* * *} \\
(0.301)\end{array}$ & $\begin{array}{l}3.989^{* * *} \\
(0.313)\end{array}$ & $\begin{array}{l}5.024^{* * \star} \\
(0.688)\end{array}$ & $\begin{array}{l}4.635^{* * *} \\
(0.701)\end{array}$ \\
\hline Rel. capital ratio & $\begin{array}{l}3.329^{* * *} \\
(0.448)\end{array}$ & $\begin{array}{l}3.669^{* * *} \\
(0.450)\end{array}$ & $\begin{array}{l}-2.319^{* * *} \\
(0.666)\end{array}$ & $\begin{array}{l}-4.381^{* * *} \\
(0.694)\end{array}$ \\
\hline Rel. human $\mathrm{K}$ ratio & $\begin{array}{l}0.183^{* * *} \\
(0.0312)\end{array}$ & $\begin{array}{l}0.226^{\star \star *} \\
(0.0319)\end{array}$ & $\begin{array}{l}0.172^{\star \star *} \\
(0.0355)\end{array}$ & $\begin{array}{l}0.300^{\star * *} \\
(0.0384)\end{array}$ \\
\hline Rel. labour ratio & $\begin{array}{l}0.0796 \\
(0.0435)\end{array}$ & $\begin{array}{l}0.0290 \\
(0.0436)\end{array}$ & $\begin{array}{l}1.889^{* * *} \\
(0.134)\end{array}$ & $\begin{array}{l}1.841^{* * *} \\
(0.134)\end{array}$ \\
\hline gamma & $\begin{array}{l}-0.134^{\star * \star} \\
(0.0155)\end{array}$ & $\begin{array}{l}-0.146^{* * *} \\
(0.0156)\end{array}$ & $\begin{array}{l}0.0757^{* *} \\
(0.0230)\end{array}$ & $\begin{array}{l}0.149^{\star * *} \\
(0.0241)\end{array}$ \\
\hline phi & $\begin{array}{l}0.204^{\star * \star} \\
(0.0358)\end{array}$ & $\begin{array}{l}0.187^{\star \star \star} \\
(0.0355)\end{array}$ & $\begin{array}{l}0.0419 \\
(0.0346)\end{array}$ & $\begin{array}{l}0.0347 \\
(0.0341)\end{array}$ \\
\hline freedom & $\begin{array}{l}0.598^{\star * *} \\
(0.0286)\end{array}$ & $\begin{array}{l}0.580^{* * *} \\
(0.0286)\end{array}$ & $\begin{array}{l}0.320^{\star * \star} \\
(0.0257)\end{array}$ & $\begin{array}{l}0.304^{* * \star} \\
(0.0253)\end{array}$ \\
\hline $\mathrm{fta}$ & $\begin{array}{l}0.433^{\star * *} \\
(0.0826)\end{array}$ & $\begin{array}{l}0.370^{\star * \star} \\
(0.0853)\end{array}$ & $\begin{array}{l}0.378^{\star \star \star} \\
(0.0751)\end{array}$ & $\begin{array}{l}0.342^{* \star *} \\
(0.0738)\end{array}$ \\
\hline \multicolumn{5}{|l|}{ Multilateral variables } \\
\hline wg & & $\begin{array}{l}0.160 \\
(0.0939)\end{array}$ & & $\begin{array}{l}-0.0246 \\
(0.0471)\end{array}$ \\
\hline ws & & $\begin{array}{l}-58.01^{* * *} \\
(14.37)\end{array}$ & & $\begin{array}{l}27.75^{\star *} \\
(9.307)\end{array}$ \\
\hline wk & & $\begin{array}{l}1.324^{*} \\
(0.555)\end{array}$ & & $\begin{array}{l}-0.130 \\
(0.280)\end{array}$ \\
\hline wh & & $\begin{array}{l}-0.714^{\star *} \\
(0.268)\end{array}$ & & $\begin{array}{l}-0.648^{* * *} \\
(0.136)\end{array}$ \\
\hline wl & & $\begin{array}{l}0.686^{\star * \star} \\
(0.189)\end{array}$ & & $\begin{array}{l}0.549^{* * *} \\
(0.0902)\end{array}$ \\
\hline wgamma & & $\begin{array}{l}-0.0180 \\
(0.0228)\end{array}$ & & $\begin{array}{l}0.00831 \\
(0.0114)\end{array}$ \\
\hline wphi & & $\begin{array}{l}-0.164 \\
(0.157)\end{array}$ & & $\begin{array}{l}0.0437 \\
(0.0765)\end{array}$ \\
\hline wfreedom & & $\begin{array}{l}0.0701 \\
(0.381)\end{array}$ & & $\begin{array}{l}-0.165 \\
(0.184)\end{array}$ \\
\hline wfta & & $\begin{array}{l}1.431 \\
(2.039)\end{array}$ & & $\begin{array}{l}-0.390 \\
(0.981)\end{array}$ \\
\hline _cons & $\begin{array}{l}-59.20^{\star \star *} \\
(3.345)\end{array}$ & $\begin{array}{l}-56.85^{\star \star *} \\
(3.836)\end{array}$ & $\begin{array}{l}-61.34^{* * *} \\
(6.285)\end{array}$ & $\begin{array}{l}-89.31^{\text {*** }} \\
(7.099)\end{array}$ \\
\hline $\mathrm{N}$ & 4307 & 4307 & 4307 & 4307 \\
\hline
\end{tabular}

Country pair effects

(4)

with 3rd country

Note: Standard errors are in parentheses. ${ }^{*},{ }^{* *}$ and ${ }^{* * *}$ indicate significance at the five per cent level, one per cent and 0.1 per cent levels, respectively. 


\section{Performance}

The performance measure is the residual, or the normally distributed error term, which shows the actual FDI value relative to what the model of FDI determinants predicts. The composite error terms are:

udit $=$ edi $+\eta$ dit for the country pair fixed effects model and

udit $=\mathrm{ed}+\eta$ dit for the country specific fixed effects model

where $\eta$ is the usual normally distributed error term and e is the fixed effect. The difference is that the fixed effect error component, e, is fixed over pairs or source and destination, $\mathrm{d}$ and $\mathrm{i}$, for the country pair fixed effects and for only the source country, $\mathrm{d}$, in the country specific effects model.

Gravity models of trade have been used for estimating unexhausted or untapped trade by estimating a trade potential or natural trade volume (Baldwin 1994; Baldwin et al. 1997; Egger 2002). They define unexhausted trade as the deviation of actual trade to what the model predicts as the natural rate, estimated by the determinants and their parameter estimates. Egger (2008) applies the concept to FDI and calculates bilateral FDI potentials and deviations from potentials for Austrian FDI.

Actual FDI deviates from what the determinants predict due to measurement error or because of omitted variables which are omitted because of various reasons including their difficulty to measure.

Estimation of an FDI model without inclusion of some resistance variables has the potential for omitted variable bias. Yet the choice of explanatory variables differs from model to model. Which resistance variables should be included in the? The answer to this is to follow the theory and use a model with theoretical underpinnings. Many studies include resistance variables of interest in explaining trade or FDI, however, often without justifiable reasoning other than statistical significance and obtaining parameter estimates for policy implications. FDI models such as that of Egger and Pfaffermayr (2004), Baltagi et al. (2007) do not include subjective resistances as their derivations from theory do not allow for them (except for the host-country risk variable that is included without explanation or theoretical basis).

In calculating FDI potentials, Egger (2008) does not use a model of FDI that has any theoretical underpinnings and therefore it is not clear that the choice of determinants that are included are appropriate. In fact, Egger models FDI activity (three models using foreign assets, number of foreign affiliates and number of foreign employees) using GDP as the only explanatory variable.

Figure 1 shows the performance of FDI in China by Japanese, German, US and British firms. The data for Figure 1, as well as performance of Canadian, French and Dutch firms, is shown in Table 4 with results for both country-specific and country-pair 
fixed effects. Figure 2 shows performance of Japanese FDI in China, Hong Kong and the rest of the world. When the residual takes a value of zero it means that FDI was at the level that the model predicts given the scale, endowment ratios and other determinants. A value above this means higher than predicted performance and below means low performance.

Figure 1 FDI stock performance into China, controlling for country-pair effects, 19822006

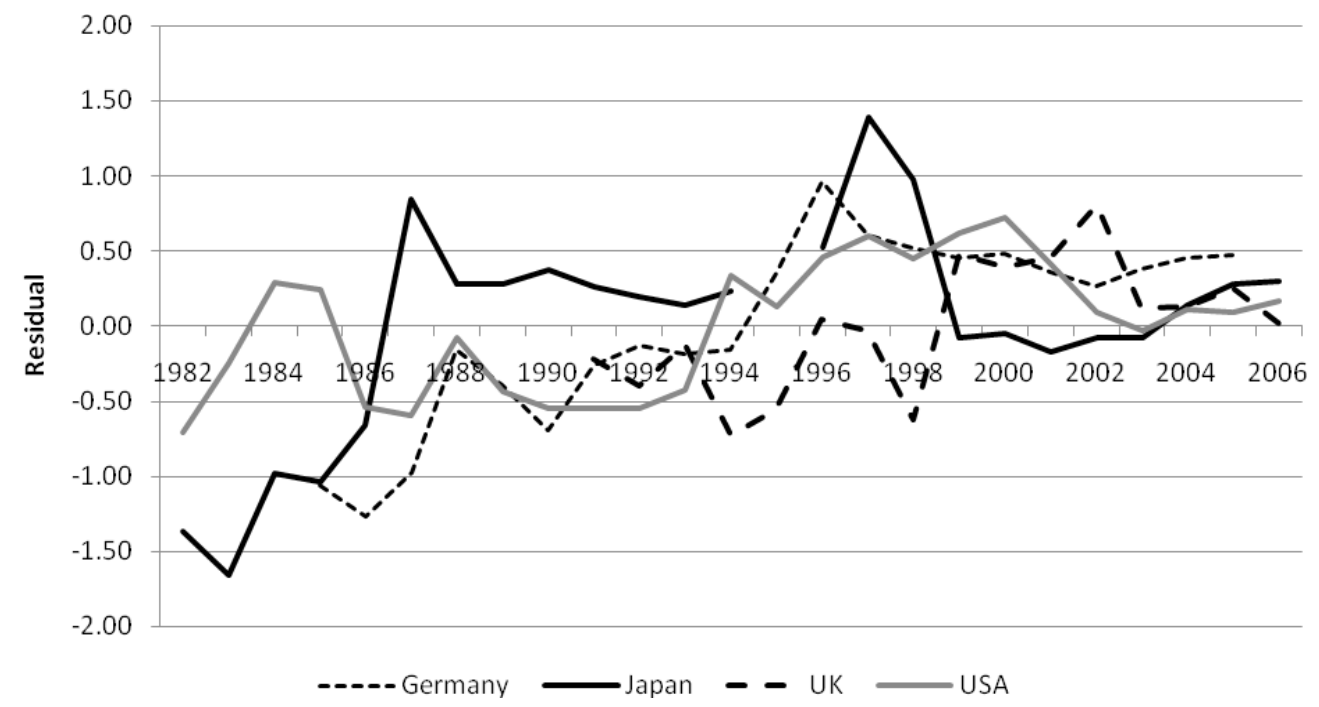

Source: Author's calculations.

Note: Japanese outward FDI flows and stocks are not available for the year 1995 in the OECD data set. Pre-1995 data and post 1995 FDI data are sourced from different Japanese statistical agencies or computed on a different basis so a structural dummy variable was included in the estimation.

Controlling for country-pair fixed effects allows a measure of the changes in FDI between country pairs over time, holding all else constant. This specification controls for observable and unobservable factors that do not change over time, among them geographical distance.

Controlling for country-specific fixed effects does not change the shape of the lines in Figure 1 significantly, but it changes the relative positioning of each source country and their ranking (Table 4). Japanese FDI to China is the highest performing in 2006, after controlling for the determinants, and is in fact the highest performing for the periods 1986 to 1994 and 1997 and 1998, similar to the case where country-pair fixed effects are controlled for. Japanese FDI outperformed FDI from all other source countries in the sample between 1987 and 1991, and again in 1997 and 1998 (Figure 1 and Table $4)$. 
When measuring the performance of FDI relative to what its determinants would predict, it is also useful to consider not controlling for those country-pair fixed effects that are unobservable. Distance is already accounted for in the model estimation and there is a chance that other unobservable factors that stay constant between country pairs reveal a different story from that of Figure 1. Both sets of results are presented in Table 5 with the panel on the right hand side reflecting the case where country-specific fixed effects are controlled for. The numbers from Figure 1 are presented in the left hand panel of Table 4 which includes Canada, France and the Netherlands as well.

Table 4 FDI stock performance into China

\begin{tabular}{|c|c|c|c|c|c|c|c|c|c|c|c|c|c|c|c|}
\hline \multirow[b]{2}{*}{ Year } & \multicolumn{7}{|c|}{ Controlling for country-pair fixed effects } & \multicolumn{8}{|c|}{ Controlling for country-specific fixed effects } \\
\hline & Can & Fra & Ger & Jpn & Ned & UK & US & Year & Can & Fra & Ger & Jpn & Ned & UK & US \\
\hline 1982 & & & & -1.4 & & & -0.7 & 1982 & & & & -2.4 & & & -2.3 \\
\hline 1983 & & & & -1.7 & & & -0.2 & 1983 & & & & -2.7 & & & -2.0 \\
\hline 1984 & & & & -1.0 & & & 0.3 & 1984 & & & & -2.1 & & & -1.6 \\
\hline 1985 & & & -1.1 & -1.0 & & & 0.2 & 1985 & & & -2.9 & -2.5 & & & -2.0 \\
\hline 1986 & & & -1.3 & -0.7 & & & -0.5 & 1986 & & & -3.1 & -2.1 & & & -2.8 \\
\hline 1987 & & -0.5 & -1.0 & 0.8 & & & -0.6 & 1987 & & -2.1 & -2.7 & -0.7 & & & -3.2 \\
\hline 1988 & & -0.5 & -0.2 & 0.3 & & & -0.1 & 1988 & & -2.1 & -1.9 & -1.2 & & & -2.8 \\
\hline 1989 & & -0.5 & -0.4 & 0.3 & & & -0.4 & 1989 & & -2.4 & -2.0 & -0.9 & & & -1.8 \\
\hline 1990 & & -0.4 & -0.7 & 0.4 & & & -0.5 & 1990 & & -2.1 & -2.2 & -1.1 & & & -2.2 \\
\hline 1991 & -0.8 & -0.2 & -0.3 & 0.3 & & -0.2 & -0.5 & 1991 & -3.0 & -1.7 & -1.8 & -0.9 & & -2.1 & -2.1 \\
\hline 1992 & -0.6 & 0.3 & -0.1 & 0.2 & & -0.4 & -0.5 & 1992 & -2.6 & -1.2 & -1.6 & -0.7 & & -2.1 & -2.0 \\
\hline 1993 & 0.7 & -0.1 & -0.2 & 0.1 & -1.6 & -0.1 & -0.4 & 1993 & -1.2 & -1.4 & -1.6 & -0.7 & -3.6 & -1.9 & -1.8 \\
\hline 1994 & 0.5 & 0.4 & -0.2 & 0.2 & 0.4 & -0.7 & 0.3 & 1994 & -1.4 & -0.9 & -1.7 & -0.5 & -1.7 & -2.6 & -1.1 \\
\hline 1995 & 0.6 & 0.5 & 0.4 & & 0.4 & -0.6 & 0.1 & 1995 & -1.1 & -0.7 & -1.2 & & -1.6 & -2.3 & -1.1 \\
\hline 1996 & 0.4 & -0.1 & 1.0 & 0.5 & 0.2 & 0.0 & 0.5 & 1996 & -1.4 & -1.1 & -0.4 & -0.7 & -1.7 & -1.7 & -0.8 \\
\hline 1997 & 0.2 & 0.2 & 0.6 & 1.4 & 0.4 & 0.0 & 0.6 & 1997 & -1.6 & -0.8 & -0.7 & 0.1 & -1.6 & -1.8 & -0.7 \\
\hline 1998 & 0.0 & 0.3 & 0.5 & 1.0 & 0.2 & -0.6 & 0.4 & 1998 & -2.0 & -0.8 & -0.8 & -0.3 & -1.9 & -2.4 & -0.9 \\
\hline 1999 & 0.3 & 0.3 & 0.5 & -0.1 & 0.4 & 0.5 & 0.6 & 1999 & -1.8 & -0.9 & -0.9 & -1.4 & -1.7 & -1.3 & -0.8 \\
\hline 2000 & 0.0 & 0.3 & 0.5 & 0.0 & 0.4 & 0.4 & 0.7 & 2000 & -2.2 & -0.9 & -0.9 & -1.4 & -1.7 & -1.5 & -0.7 \\
\hline 2001 & -0.2 & 0.2 & 0.4 & -0.2 & 0.3 & 0.5 & 0.4 & 2001 & -2.5 & -1.1 & -1.1 & -1.6 & -1.9 & -1.5 & -1.2 \\
\hline 2002 & -0.4 & 0.1 & 0.3 & -0.1 & 0.1 & 0.8 & 0.1 & 2002 & -2.6 & -1.0 & -1.0 & -1.3 & -1.9 & -1.1 & -1.4 \\
\hline 2003 & -0.3 & 0.0 & 0.4 & -0.1 & 0.0 & 0.1 & 0.0 & 2003 & -2.4 & -1.2 & -0.9 & -1.3 & -2.1 & -1.9 & -1.4 \\
\hline 2004 & -0.2 & -0.1 & 0.5 & 0.1 & -0.4 & 0.1 & 0.1 & 2004 & -2.2 & -1.3 & -0.9 & -1.1 & -2.6 & -2.0 & -1.3 \\
\hline 2005 & -0.2 & -0.1 & 0.5 & 0.3 & -0.4 & 0.3 & 0.1 & 2005 & -2.3 & -1.4 & -0.9 & -1.0 & -2.5 & -1.9 & -1.4 \\
\hline 2006 & 0.0 & -0.1 & & 0.3 & -0.4 & 0.0 & 0.2 & 2006 & -2.1 & -1.4 & & -0.9 & -2.7 & -2.2 & -1.5 \\
\hline Fixed & & & & & & & & Fixed & & & & & & & \\
\hline Effect & 7.8 & 6.7 & 6.6 & 6.9 & 8.7 & 6.4 & 4.1 & Effect & 0.8 & 1.4 & -0.3 & -2.2 & 8.7 & 2.2 & -4.7 \\
\hline Notes & & $\begin{array}{l}\text { 1. Ca } \\
\text { 2. Jap } \\
\text { data } \\
\text { agenc } \\
\text { estim }\end{array}$ & $\begin{array}{l}=\mathrm{Ca} \\
\text { nese } \\
\text { t. Pre } \\
\text { es or } \\
\text { tion. }\end{array}$ & $\begin{array}{l}\text { ada, } F \\
\text { utwarc } \\
1995 \\
\text { mput }\end{array}$ & $\begin{array}{l}\mathrm{Ca}=\mathrm{Fr} \\
\mathrm{FDI} \\
\text { lata an } \\
\text { ed on }\end{array}$ & $\begin{array}{l}\text { ance, } \\
\text { fows a } \\
\text { d post } \\
\text { a diffe }\end{array}$ & $\begin{array}{l}\text { Ger }= \\
\text { and st } \\
\mathrm{t}-199 \\
\text { rent b }\end{array}$ & $\begin{array}{l}\text { nany, } \\
\text { Ire not } \\
\text { data } \\
\text { o a str }\end{array}$ & $\begin{array}{l}\mathrm{l}=\mathrm{Ja} \\
\text { vailab } \\
\text { sour } \\
\text { tural }\end{array}$ & $\begin{array}{l}\text { pan, } \\
\text { le for } \\
\text { ced } f \\
\text { dum }\end{array}$ & $\begin{array}{l}\text { Ted }= \\
\text { the ye } \\
\text { om dif } \\
\text { y varia }\end{array}$ & $\begin{array}{l}\text { Nether } \\
\text { ar } 199 \\
\text { ferent } \\
\text { ble wa }\end{array}$ & $\begin{array}{l}\text { lands } \\
5 \text { in } t \\
\text { Japan } \\
s \text { inc }\end{array}$ & $\begin{array}{l}\mathrm{US}= \\
\text { OEC } \\
\text { se stat } \\
\text { ded in }\end{array}$ & $\begin{array}{l}\text { JSA. } \\
\text { D } \\
\text { stical } \\
\text { the }\end{array}$ \\
\hline
\end{tabular}


Figure 2 shows Japanese FDI performance into China, Hong Kong and an average of the rest of the world. The reason Hong Kong is included is that FDI into Hong Kong may ultimately be destined for China through Hong Kong as has been the case with trade flows, in earlier times (Hanson and Feenstra 2001). Japanese FDI performance in China is represented by the same line in Figures 1 and 2.

Figure 2 Japanese FDI performance controlling for country-pair effects

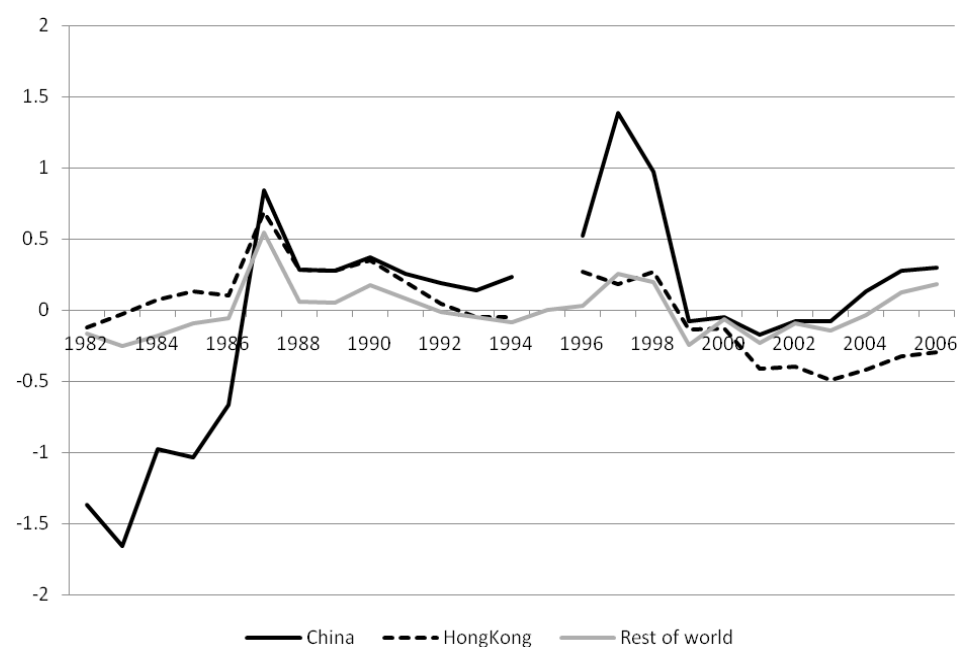

Source: Author's calculations.

Note: Japanese outward FDI flows and stocks are not available for the year 1995 in the OECD data set. Pre-1995 data and post 1995 FDI data are sourced from different Japanese statistical agencies or computed on a different basis so a structural dummy variable was included in the estimation.

It is useful to review Japanese FDI performance in China in three sub-periods. The first is the underperformance in the early 1980s, the second is the high performance in the 1990s and lastly the final period from 2001.

\section{The 1980s}

Japanese FDI was well below what the determinants predicted until the mid-1980s. The rise occurred around the time of the Plaza Accord and the subsequent rapid appreciation of the Japanese yen. The sudden appreciation of the Japanese yen made Japanese exports less competitive and so many Japanese MNEs shifted production offshore.

However, judging from Figure 2, the Plaza Accord was not the cause of Japanese FDI increasing in China, as Japanese FDI to Hong Kong and elsewhere was performing close to what determinants would predict throughout this period. The Plaza Accord affected all Japanese outward FDI in a similar way as it was not just an appreciation vis a vis 
the Chinese currency but against the US dollar and most international currencies. Figure 1 shows performance of German FDI in that period confirms that the Plaza Accord alone was not the cause of the rise in performance.

The under-utilisation of FDI potential was related to the still relatively closed Chinese domestic market. Japanese firms were especially risk averse in investing in China when there was little access to domestic markets and they feared that Chinese partners would appropriate their technology for production directed at their home and other international markets (the so called 'boomerang effect') (Fukuda 1998; Luo 2001). Only 16 per cent of Japanese FDI in China was by large MNEs in 1986, with FDI being dominated by small and medium enterprises (Luo 2001:74). There was a fundamental change in Japanese perceptions of investment in China around 1986-1987 in response to a strategic shift in investment policy in China as access to domestic markets by foreign investors was opened up. This opening up was undertaken in conjunction with the signing of the bilateral investment treaty (BIT) of 1988. By 1987 FDI performance had become positive and relatively high. The rapid inflow of FDI into China from Japan was helped as the BIT reduced uncertainty. It is difficult to separate out the effect of the BIT and determine causation as it is not clear whether the BIT was the cause of the initial inflow of FDI or a response to it.

The period leading up to 1986 can be characterised as Japanese FDI facing high resistances in moving to China because of an FDI policy environment that limited access to domestic markets and caused particular uncertainty about investing in China within Japanese firms. Other resistances, such as certain barriers to foreign firm entry that could be overcome at a cost, such as by entry into the Chinese market via Hong Kong, also played a role, but the high level of uncertainty about Chinese policy and the asymmetric information from a less open market would have been the resistances that dominated.

1986 was the year that Chinese policy changed in two significant ways. Firstly, fiscal and financial incentives were given to attract foreign companies in a move to open up China to the rest of the world. ${ }^{5}$ In fact, this was the year that solely foreign-owned enterprises were legalised in China (National People's Congress 1986). Secondly, and perhaps more significantly, this was the year that talks resumed for China to enter the GATT. The bandwagon effect (Knickerbocker 1973) where MNEs will follow rivals into a foreign market can be seen by the sudden flood of Japanese FDI inflow at that time.

\section{The 1990s}

Performance in the 1990s was very high as Japanese FDI into China accelerated and was significantly higher than the model predicts. The peak came in 1997 before a drop around the time of the Asian financial crisis. The 1990s were when China embarked on 
large scale trade liberalisation and other reforms aimed at WTO accession (Drysdale and Song 2000; Lardy 2002). Commitment to the global trading system through unilateral trade liberalisation and reforms that were difficult, if not impossible, to reverse gave Japanese and other firms confidence in investing in China (Drysdale and Song 2000). Trade liberalisation would have reduced tangible resistances such as barriers to trade, but again, intangible resistances would seem to have played a larger role as China's reforms aimed at moving towards a market economy system closer to what the Japanese firms were used to would have reduced uncertainty. The gradual opening up of the Chinese domestic market would also reduce asymmetric information.

Survey results of potential destinations for Japanese FDI have consistently ranked China as number one. The Survey Report on Overseas Business Operations by Japanese Manufacturing Companies undertaken every year (since 1989) by the Japan Bank for International Cooperation Institute (JBICI) is a comprehensive survey with an average of around 600 Japanese MNEs surveyed a year in the last five years involving over 10,000 overseas affiliates. Figure 3 shows the destinations which Japanese investors see as most promising countries/regions for overseas business operations and their relative rank.

Figure 3 Promising countries/regions for Japan overseas business operations over the medium term, 1995-2007

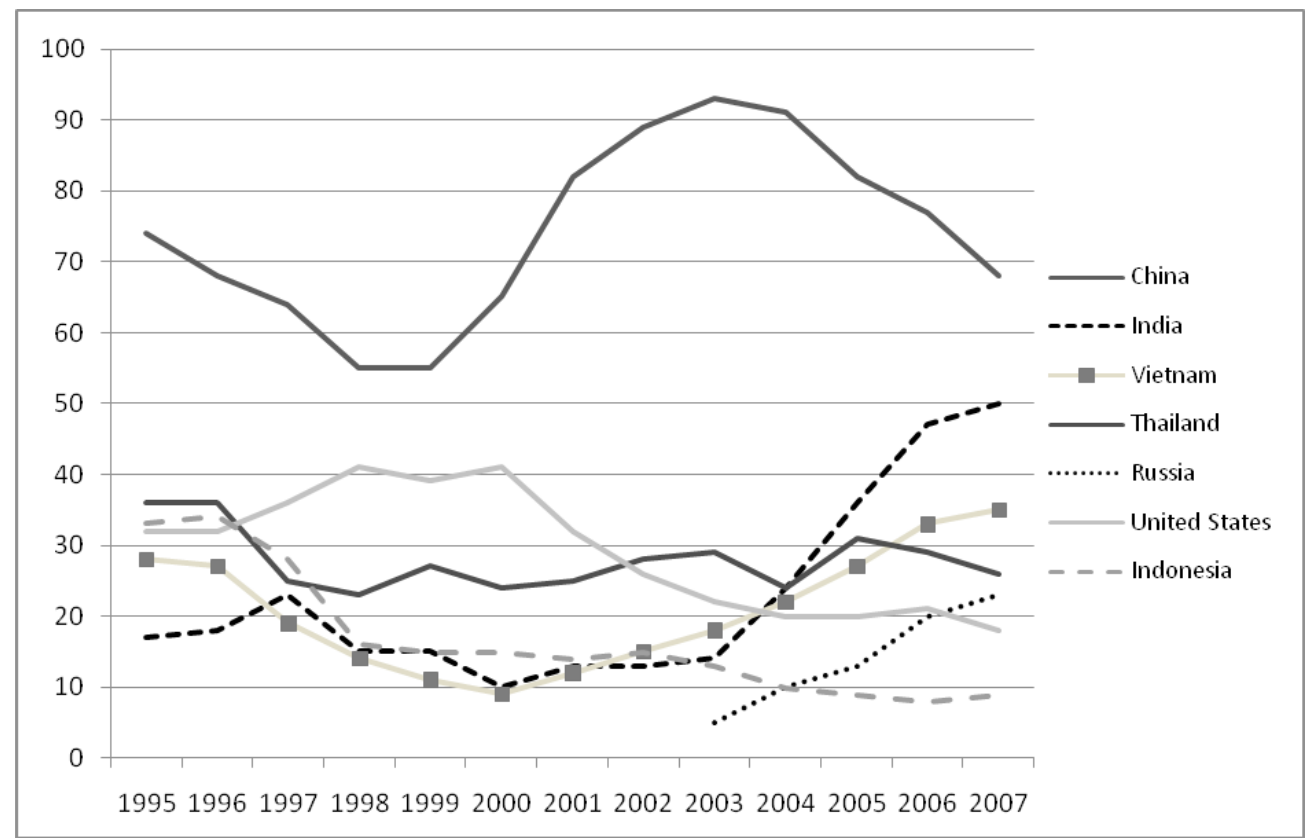

Source: JBICI, various years. 
In the 2007 JBICI survey 80 per cent of companies cited 'future growth potential of local market' as a reason for operating in China. China has been ranked number one every year since at least 1995, but its relative position peaked in 2003 and has been falling since. India and Vietnam have been gaining, as has Russia, in relative terms.

Resistances to FDI were low during this period as the BIT and institutional reforms reduced resistances which continued to fall as China liberalised trade. Figure 3 reveals the growth of confidence that Japanese firms had in investing in China.

\section{The 2000s}

The period from 1997 is of particular interest for Japanese FDI into China as there is a significant and large fall and then, in 2001, a small yet significant trend upwards. The period from 1999 to 2005 shows the United States, United Kingdom and Germany perform much better than Japan (Figure 1) and compared to what the determinants would predict.

Is the underperformance of Japanese FDI in China during that time because Japanese firms faced more resistances compared to firms from other source countries? The rise of China as by far the most attractive destination for FDI from 1998 shows almost an inverse relationship to the performance of Japanese FDI in China which falls in that period. An upside down u-shaped curve for the survey in Figure 3 is almost a mirror image of the u-shaped curve of performance between 1998 and 2006.

To answer this question, Japanese FDI to the rest of the world, as well as the political distance between Japan and China during that time, are both discussed.

Figure 2 shows that Japanese FDI movements in different destinations are generally in the same directions. Hong Kong appears to have played a role as a substitute FDI destination before 1986 as uncertainty in dealing with China was high. The signing of the bilateral investment treaty in 1988 reduced uncertainty and perhaps meant that Hong Kong was used less as a channel through which to send FDI into China with Japanese FDI instead going into China directly. This can be seen by Japanese FDI to Hong Kong falling over time. FDI flows to the rest of the world are much closer to what the model predicts. The important finding in Figure 2 is that Japanese FDI to China outperformed Japanese FDI to the rest of the world in every year since 1987.

For FDI into China, there is a turning point around 2001 and a steady rise in Japanese FDI performance since (Figures 1 and 2). Japanese FDI into China may not have been performing well compared to other source country FDI but it is above Japanese FDI performance to the rest of the world and only marginally under its predicted value (the value zero in Table 4) for a the period 1999-2003.

The political distance variables for Japanese 'sentiment' towards China are presented 
in Figure 4, separated into both positive and negative variables (negative was subtracted from positive for the net variable in the earlier analysis). The year 2001 was an interesting year for the Japan-China relationship as it marked the beginning of a period of high political tensions which resulted in suspension of leadership visits for six years and it coincided with China becoming a member of the World Trade Organisation (WTO). Both the negative and positive variables rose significantly in 2001.

Figure 4 Japanese political distance towards China, 1990-2004

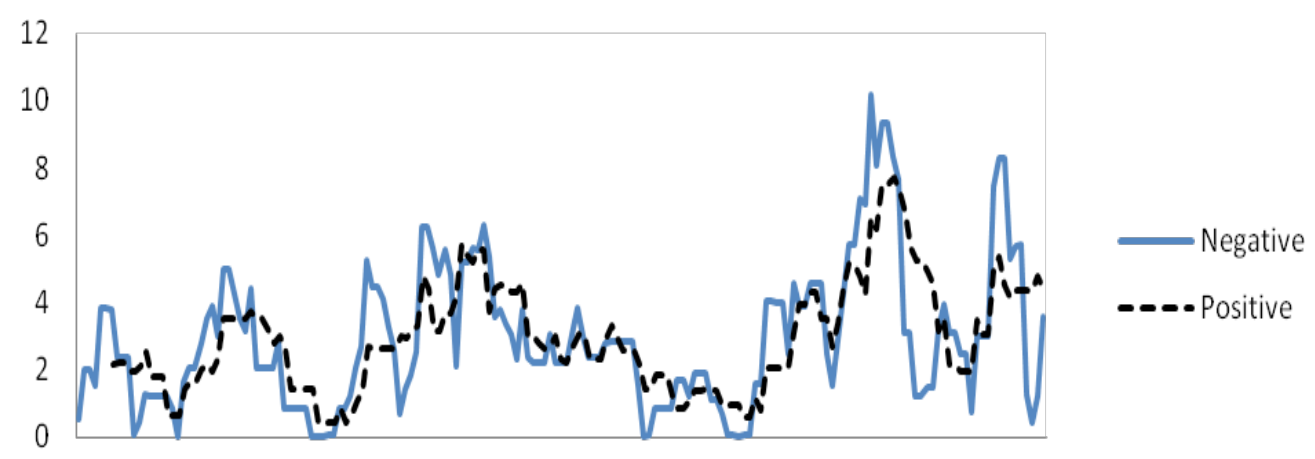

199019911992199319941995199619971998199920002001200220032004

Source: Data are extracted from King (2003).

Note: Negative events are a 6-month moving average and positive events are a 12-month moving average.

The net effect of the political positives and negatives are difficult to determine from Figure 4 alone. Given the Goldstein (1992) weighting of events, Figure 4 shows China's WTO accession offsetting the rising negative political sentiment with positive economic sentiment. The next section investigates the effect of political distance on FDI.

\section{Political Distance}

A measure of political distance between countries is added to the analysis to capture the effects of internal uncertainty on FDI and the results of this analysis are presented in Table 4. The variable is from King (2006), called Integrated Data for Events Analysis (IDEA), and is event data coded from Reuters Business Briefs. Events, both positive and negative actions, are coded into monthly bilateral data and aggregated to annual data over the period 1990-2004. ${ }^{6}$ Positive and negative data are weighted in a scale of severity in similar yet more detailed fashion to a well established body of literature on the interaction between trade and conflict or cooperation. Mansfield and Pollins (2003) survey that literature and review the evolution of the data methodology. The data are described in more detail in the Data Annex. 
Asia Pacific Economic Papers

Table 5 Political distance and FDI: country-specific fixed effects

Country-specific fixed effects

(1)

flows
(2)

stocks
With time lag

(3)

(4)

stocks

\begin{tabular}{|c|c|c|c|c|}
\hline \multirow[t]{3}{*}{ distance } & - & - & - & - \\
\hline & $0.533^{* * *}$ & $0.794^{* * *}$ & $0.627^{* * *}$ & $0.865^{\star * *}$ \\
\hline & $(0.0819)$ & $(0.0723)$ & $(0.0870)$ & $(0.0776)$ \\
\hline \multirow[t]{2}{*}{ g } & $1.690^{* * *}$ & $1.447^{* * *}$ & $1.935^{\star * *}$ & $1.551^{* \star *}$ \\
\hline & $(0.185)$ & $(0.156)$ & $(0.180)$ & $(0.157)$ \\
\hline \multirow[t]{2}{*}{ S } & $4.186^{\star * *}$ & $5.100^{* * *}$ & $4.024^{* * *}$ & $5.002^{\star \star *}$ \\
\hline & $(0.486)$ & $(0.410)$ & $(0.487)$ & $(0.417)$ \\
\hline \multirow[t]{2}{*}{ k } & $3.000^{* * *}$ & $3.333^{* * *}$ & $4.181^{* * *}$ & $4.052^{* * *}$ \\
\hline & $(0.720)$ & $(0.575)$ & $(0.686)$ & $(0.553)$ \\
\hline \multirow[t]{2}{*}{ h } & $0.188^{* * *}$ & $0.294^{* * *}$ & $0.176^{\star * *}$ & $0.295^{\star * *}$ \\
\hline & $(0.0471)$ & $(0.0388)$ & $(0.0502)$ & $(0.0413)$ \\
\hline \multirow[t]{2}{*}{ I } & -0.0405 & -0.0461 & -0.0208 & -0.0605 \\
\hline & $(0.0617)$ & $(0.0547)$ & $(0.0637)$ & $(0.0569)$ \\
\hline \multirow[t]{2}{*}{ gamma } & $-0.113^{\star * *}$ & $-0.135^{\star * *}$ & $-0.156^{* * *}$ & $-0.161^{* * *}$ \\
\hline & $(0.0248)$ & $(0.0199)$ & $(0.0235)$ & $(0.0191)$ \\
\hline \multirow[t]{2}{*}{ phi } & 0.0563 & $0.201^{* * *}$ & $0.124^{*}$ & $0.244^{* * *}$ \\
\hline & $(0.0538)$ & $(0.0462)$ & $(0.0540)$ & $(0.0472)$ \\
\hline \multirow[t]{2}{*}{ freedom } & $0.595^{\star * \star}$ & $0.759^{* * *}$ & $0.518^{* * *}$ & $0.648^{* * *}$ \\
\hline & $(0.0455)$ & $(0.0400)$ & $(0.0453)$ & $(0.0401)$ \\
\hline \multirow[t]{2}{*}{ wg } & 0.418 & 0.0868 & 0.236 & -0.122 \\
\hline & $(0.683)$ & $(0.639)$ & $(0.695)$ & $(0.653)$ \\
\hline \multirow[t]{2}{*}{ ws } & $-115.7^{\star * *}$ & $-122.6^{\star * *}$ & $-110.7^{\star * *}$ & $-117.7^{\star \star *}$ \\
\hline & $(24.74)$ & $(22.87)$ & $(25.04)$ & $(23.41)$ \\
\hline \multirow[t]{2}{*}{ wk } & 0.767 & 4.427 & 2.663 & 5.061 \\
\hline & (3.182) & $(2.494)$ & (3.317) & $(2.614)$ \\
\hline \multirow[t]{2}{*}{ wh } & 1.101 & $-1.198^{\star *}$ & 0.486 & $-1.711^{* * *}$ \\
\hline & $(0.700)$ & $(0.427)$ & $(0.712)$ & $(0.443)$ \\
\hline \multirow[t]{2}{*}{$w l$} & 0.504 & 0.209 & 0.576 & 0.277 \\
\hline & $(0.429)$ & $(0.294)$ & $(0.437)$ & $(0.303)$ \\
\hline \multirow[t]{2}{*}{ wgamma } & -0.0948 & $-0.234^{*}$ & -0.164 & $-0.259^{*}$ \\
\hline & $(0.123)$ & $(0.0972)$ & $(0.127)$ & $(0.101)$ \\
\hline \multirow[t]{2}{*}{ wphi } & -0.660 & 0.225 & -0.509 & 0.341 \\
\hline & $(0.516)$ & $(0.235)$ & $(0.528)$ & $(0.243)$ \\
\hline \multirow[t]{2}{*}{ wfreedom } & 2.403 & -1.601 & 1.555 & $-2.619^{*}$ \\
\hline & (1.678) & $(1.302)$ & (1.691) & $(1.330)$ \\
\hline \multirow[t]{2}{*}{$\mathrm{fta}$} & $0.458^{* \star \star}$ & $0.312^{* \star}$ & $0.483^{* * *}$ & $0.332^{* *}$ \\
\hline & $(0.135)$ & $(0.119)$ & $(0.137)$ & $(0.121)$ \\
\hline \multirow[t]{2}{*}{ wfta } & 1.858 & 6.573 & -2.034 & 4.017 \\
\hline & (4.999) & (3.885) & (5.092) & (3.988) \\
\hline \multirow[t]{2}{*}{ politics } & $0.00531^{* * *}$ & $0.00445^{* * *}$ & $-0.00130^{* * *}$ & $-0.00118^{* *}$ \\
\hline & $(0.000798)$ & $(0.000724)$ & $(0.000375)$ & $(0.000362)$ \\
\hline \multirow[t]{2}{*}{ wpolitics } & 0.00907 & 0.0108 & 0.0107 & 0.0167 \\
\hline & $(0.0115)$ & $(0.00895)$ & $(0.0118)$ & $(0.00930)$ \\
\hline \multirow[t]{2}{*}{ _cons } & $-48.90^{* *}$ & -11.95 & $-45.07^{\star *}$ & 1.318 \\
\hline & $(17.25)$ & $(14.66)$ & (17.38) & (16.14) \\
\hline $\mathrm{N}$ & 2026 & 2602 & 1943 & 2478 \\
\hline
\end{tabular}

Note: Standard errors in parentheses

${ }^{*} \mathrm{p}<0.05,{ }^{* *} \mathrm{p}<0.01,{ }^{* *} \mathrm{p}<0.001$ 
The negative events are subtracted from the positive events to obtain a measure of net political closeness. As in utility theory the assumption here is that positive events cancel out negative events to a certain extent. Therefore a positive value for the political variable indicates political closeness and a negative value indicates widening political distance. A movement in a positive direction implies a narrowing political distance. The results reported in Table 5 are based on a political distance variable that has FDI source country reporting news events towards the FDI host country. Different constructions of the political distance variable are tested below.

The political distance measure is not controlled for in the earlier analysis of FDI performance as their inclusion will limit the analysis to the period 1990-2004. Columns 1 and 2 in Table 5 show results similar to the results before but with political distance included.

There is ample evidence that causality runs both ways between trade and political distance and that the lag lengths of causation vary (Pollins 1989a; Pollins 1989b; Reuveny and Kang 2003). To account for this in the link between FDI and political distance, a lagged political distance variable is included. The one-year lag is roughly consistent with other findings and more appropriate than a two-year lag (Reuveny and Kang 2003) and also controls for causality running from economic distance to political distance. There is much evidence that changes in economic relations influence political relations (Polachek 1980; Mansfield and Pollins 2003). Improvements in a political relationship would not be expected to have impacts on the economic relationship, and vice versa, immediately, but often with a lag as economic agents and foreign policy stances adjust. The results with a lagged political distance variable are shown in columns 3 and 4 .

The results presented in Table 5 show that the measure of bilateral political distance has a statistically significant effect on FDI for both FDI stock and flows when countryspecific fixed effects are controlled for. When country-pair fixed effects are controlled for (see Appendix), this is not the case and suggests that country-pair fixed effects already control for political distance. Country-pair fixed effects control for factors in the bilateral relationship that do not change over time such as geographic distance. The fact that country-pair fixed effects seem to control for bilateral political distance may mean that there is no significant variation over time between bilateral pairs in the sample.

There is evidence of improving political relations being associated with an increase in FDI. The inverse-distance weighted political distance variable was not found to be statistically significant. The results in Table 5 only include the political distance measure for source country event analysis reporting on the FDI host country. For example, it shows that an increase in positive news reports from a source country which mention the host country - an indicator of the source country warming to the host country - is associ- 
ated with an increase in FDI from source to host. Appendix A sets out sensitivity test results where FDI from country A to country B is similarly affected by political distance measures based on reports in country B towards country A, as well as the sum of both directions of political distance. The results do not differ significantly and suggest that a measure of one country's perceptions towards another is correlated to the other country's perceptions of it.

The statistical insignificance of the political distance variable when country-pair specific fixed effects is controlled for may suggest that there is not enough variation across time in the variable despite Figure 4 showing otherwise for Japan and China.

\section{Conclusions}

FDI for the seven of the world's largest eight FDI source countries was modelled with multilateral effects. The results confirm the importance of including multilateral effects that are inverse distance weighted effects of third-country variables, which is a recent development in the literature.

A measurement of political distance is included to capture uncertainty which is internal to a bilateral economic relationship and shown to have a significant effect on FDI. A worsening of the political relationship, or widening of political distance, has the effect of reducing FDI between those two countries, holding all else constant. There was no evidence of a change in a bilateral political relationship having effect on FDI flows outside of that bilateral pair, that is, between those countries and other countries.

This result has significant implications for estimating and modelling FDI and, in particular, Japanese FDI into China which was the focus of the study. Performance of Japanese FDI into China was compared with the performance of other source country FDI into China as well as the performance of Japanese FDI to the rest of the world. This was done by creating a counterfactual, and predicting what FDI would be expected to be given the determinants of FDI flows.

Japanese FDI vastly underperformed in China in the early 1980s. In that period, risk- averse Japanese firms faced a high degree of uncertainty in investing in China and MNEs did not start to enter in any substantial scale until Chinese policy shifted in the late 1980s. This move towards opening up of the Chinese domestic economy coincided with the Plaza Accord, but the signing of the BIT between Japan and China had more effect. The BIT reduced uncertainty and gave investing firms a framework which increased confidence in committing resources in China.

Chinese trade liberalisation and domestic reform in the $1990 \mathrm{~s}$ - which continued China's opening up and was aimed at WTO accession — resulted in Japanese FDI perform- 
ing highly through most of the 1990s until the Asian financial crisis. The commitment from China to the international trading system as well as a gradual reforms towards a well functioning market economy, through difficult to reverse reforms, reduced resistances by increasing confidence and reducing uncertainty. The Asian financial crisis saw all Japanese FDI fall, not just to China.

Bilateral political tensions between Japan and China rose significantly in 2001 but the measure of political distance did not widen significantly as China's WTO accession offset negative political sentiment with positive economic sentiment. The result was a turning point in Japanese FDI performance which had been trending downwards. There was no significant underperformance in the period 2001-2006 when political tensions were high. In fact, compared to Japanese FDI performance overall, FDI into China did well.

\section{Data Annex}

\section{Capital stock}

Following Leamer (1984) and common practice (see Dee 2007 and Baltagi et al. 2007) the capital stock is calculated using the perpetual inventory method. This is calculated using gross fixed capital formation, $K$, at time $t$ with the formula $K t=2 t+2 t-2$ It , where $\mathrm{I}$ is investment with $\mathrm{t}$ sufficiently less than 1982 , the period under study.

\section{FDI destination (or host) economies}

Albania, Algeria, Argentina, Australia, Austria, Azerbaijan, Belgium, Belize, Benin, Bolivia, Brazil, Bulgaria, Canada, Central African Republic, Chad, Chile, China, Costa Rica, Croatia, Czech Republic, Denmark, Dominican Republic, Ecuador, El Salvador, Estonia, Finland, France, Gabon, Gambia, Georgia, Germany, Ghana, Greece, Guatemala, Guinea, Hong Kong, Hungary, Iceland, India, Indonesia, Iran, Ireland, Italy, Japan, Jordan, Latvia, Lithuania, Luxembourg, Macau, Malaysia, Mauritius, Mexico, Morocco, Namibia, Netherlands, New Zealand, Nicaragua, Norway, Pakistan, Panama, Papua New Guinea, Paraguay, Peru, Philippines, Poland, Portugal, Romania, Russia, Singapore, Slovakia, Slovenia, South Africa, South Korea, Spain, Sri Lanka, Sweden, Switzerland, Syria, Taiwan, Tanzania, Thailand, Trinidad and Tobago, Tunisia, Turkey, UAE, UK, Ukraine, Uruguay, USA. 


\section{Political distance data}

The measure of political distance is from conflict/cooperation data from King's (2003) dataset of Integrated Data for Events Analysis (IDEA) which is an extension and refinement of the World Events Interaction Survey (WEIS) data set. There are more categories of conflict and cooperation in IDEA than in WEIS or Conflict and Peace Data Bank (COPDAB). Monthly bilateral conflict and cooperation variables for Japan-China, Japan-United States and United States-China were extracted for the period 1990-2004. A net cooperation variable constructed by differencing conflict from cooperation and results below show that this practice, which is common in the literature, places too much of a restriction on the data, when compared to results of analysing conflict and cooperation separately.

Cooperation is represented by positive political or non-political event in a relationship, generally from one country towards another. A report of 'Japan increasing overseas development aid (ODA) to China' would be a cooperative event from Japan towards China. Conflict is represented by a negative political or non-political event such as 'nation-wide protests in China against Japanese interests' or 'Japanese Prime Minister's visit to Yasukuni shrine angers China'. For the net cooperation variable, a value of zero means no event or the weighted positive event (cooperation) has cancelled out the equally weighted negative event (conflict).

The events are machine coded from Reuters Business Briefs using Virtual Research Associates (VRA) software and the results are shown to be more accurate and consistent than high skill human coders (King and Lowe 2003). The events covered report most actions from one country towards another including such events categorised as comment, consult, approve, promise, grant, reward, agree, request, propose, reject, accuse, protest, deny, demand, warn, threaten and demonstrate. All events are given weights consistent with Goldstein (1992) to capture severity and extended from WEIS.

Net cooperation is used in this study. The assumption here is that a positive event will to some extent cancel out, or have the opposite effect on, a negative effect. The variables are analysed separately to confirm the importance of a net measure. Net conflict (conflict minus cooperation as opposed to the other way around) is used in other studies (Polachek 1980; Pollins 1989a). 
No. 378, 2009

\section{Appendix A Sensitivity tests}

Table Al Sensitivity tests of different risk variables

(1)

w governance

distance

g

$\mathrm{s}$

k

h

I

gamma

phi

govern

wg

ws

wk

wh

wl

wgamma

wphi

wgovern

fta

wfta

corrupt

wcorrupt

GDP source

GDP destination

freedom

whost

wfreedom

_cons

$-$

$2.307^{\text {*** }}$

(0.540)

1.382

(1.490)

(1.739)

$0.115^{*}$

$(0.0563)$

$1.534^{* * *}$

$(0.198)$
$0.254^{* * *}$

$(0.0615)$

$-0.0434$

$(0.0425)$

$0.603^{\star * *}$

$(0.120)$

0.381

$(0.343)$

$-15.34$

(15.59)

$3.193^{\star *}$

(1.203)

0.437

$(0.243)$

0.524

(0.338)

$-0.107^{*}$

(0.0457)

$-0.848^{* \star \star}$

(0.209)

$5.094^{\star * \star}$

(1.356)

$-0.0456$

(0.0939)

$-2.210$

(1.285)

(1.285)

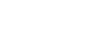

$-7.493^{\text {** }}$

(2)

w corruption $2.541^{* * *}$ (0.240) $3.003^{\star \star *}$ (0.693)

$-4.177^{\star * *}$

$(0.722)$
$0.299^{* * *}$

$(0.0430)$

$2.679^{\star * *}$

(0.150)

$0.143^{* * *}$

(0.0250)

0.0372

(0.0341)

$-0.0106$

(0.0501)

$27.48^{\star *}$

(9.198)

$-0.510$

(0.287)

$-0.505^{\star \star *}$

(0.145)

$0.449^{* * *}$

(0.0970)

0.0159

(0.0119)

0.129

(0.0819)

\section{$0.228^{* *}$}

(0.0762)

$-0.235$

(0.927)

$-0.0867^{\text {***}}$

$(0.0165)$

$-0.255$

(0.184)

\begin{tabular}{|c|c|c|}
\hline $\begin{array}{l}-68.83^{* * *} \\
(19.67)\end{array}$ & $\begin{array}{l}-72.87^{\star * *} \\
(6.969)\end{array}$ & $\begin{array}{l}2.205^{* * *} \\
(0.624) \\
1.298^{\star * *} \\
(0.116) \\
0.311^{* \star *} \\
(0.0253) \\
-2.27 \mathrm{e}-12^{*} \\
(9.22 \mathrm{e}-13) \\
0.117 \\
(0.213) \\
-98.83^{* \star *} \\
(17.90)\end{array}$ \\
\hline 2697 & 4025 & 4307 \\
\hline
\end{tabular}

(3)

separate GDPs

0.138

(0.801)

$-3.507^{* * *}$

$(0.702)$

$0.334^{* * *}$

(0.0396)

$2.014^{\star \star \star}$

(0.136)

$0.119^{* * *}$

(0.0243)

0.0439

(0.0341)

$26.71^{\text {*** }}$

(8.079)

0.407

(0.327)

$-0.456^{* *}$

$(0.145)$

$0.602^{\star \star \star}$

(0.0944)

$-0.0106$

$(0.0120)$

$-0.0120$

(0.0811)

$0.315^{\star * *}$

(0.0740)

$-2.173$

(1.213)

Note: Standard errors in parentheses

${ }^{*} p<0.05,{ }^{*}{ }^{*} p<0.01,{ }^{*}{ }^{*} p<0.001$ 
Asia Pacific Economic Papers

Table A2 Sensitivity test of directional political distance on FDI for country- specific fixed effects

\begin{tabular}{|c|c|c|c|c|c|c|}
\hline & $\begin{array}{l}\text { FDI flows } \\
\text { (1) } \\
\text { Source } \\
\text { toward } \\
\text { destination }\end{array}$ & $\begin{array}{l}(2) \\
\text { Destination } \\
\text { toward } \\
\text { source }\end{array}$ & $\begin{array}{l}(3) \\
\text { Both }\end{array}$ & $\begin{array}{l}\text { FDI stocks } \\
(4) \\
\text { Source } \\
\text { toward } \\
\text { destination }\end{array}$ & $\begin{array}{l}(5) \\
\text { Destination } \\
\text { toward } \\
\text { source }\end{array}$ & $\begin{array}{l}\text { 6) } \\
\text { Both }\end{array}$ \\
\hline distance & $\begin{array}{l}-0.533^{* * *} \\
(0.0819)\end{array}$ & $\begin{array}{l}-0.536^{\star * *} \\
(0.0815)\end{array}$ & $\begin{array}{l}-0.536^{\star * *} \\
(0.0816)\end{array}$ & $\begin{array}{l}-0.794^{* * *} \\
(0.0723)\end{array}$ & $\begin{array}{l}-0.798^{* * *} \\
(0.0721)\end{array}$ & $\begin{array}{l}-0.797^{\star * *} \\
(0.0722)\end{array}$ \\
\hline g & $\begin{array}{l}1.690^{* * *} \\
(0.185)\end{array}$ & $\begin{array}{l}1.570^{* * *} \\
(0.187)\end{array}$ & $\begin{array}{l}1.612^{\star * \star} \\
(0.186)\end{array}$ & $\begin{array}{l}1.447^{* * *} \\
(0.156)\end{array}$ & $\begin{array}{l}1.363^{* * *} \\
(0.158)\end{array}$ & $\begin{array}{l}1.397^{\star \star *} \\
(0.157)\end{array}$ \\
\hline s & $\begin{array}{l}4.186^{* * *} \\
(0.486)\end{array}$ & $\begin{array}{l}4.107^{* * *} \\
(0.484)\end{array}$ & $\begin{array}{l}4.135^{* * *} \\
(0.485)\end{array}$ & $\begin{array}{l}5.100^{* * *} \\
(0.410)\end{array}$ & $\begin{array}{l}5.039^{* * *} \\
(0.409)\end{array}$ & $\begin{array}{l}5.063^{* * *} \\
(0.409)\end{array}$ \\
\hline k & $\begin{array}{l}3.000^{* * *} \\
(0.720)\end{array}$ & $\begin{array}{l}2.781^{* * *} \\
(0.716)\end{array}$ & $\begin{array}{l}2.779^{* * *} \\
(0.720)\end{array}$ & $\begin{array}{l}3.333^{* * *} \\
(0.575)\end{array}$ & $\begin{array}{l}3.114^{* * *} \\
(0.576)\end{array}$ & $\begin{array}{l}3.145^{\star * *} \\
(0.577)\end{array}$ \\
\hline h & $\begin{array}{l}0.188^{* * *} \\
(0.0471)\end{array}$ & $\begin{array}{l}0.195^{\star \star *} \\
(0.0469)\end{array}$ & $\begin{array}{l}0.193^{\star * *} \\
(0.0470)\end{array}$ & $\begin{array}{l}0.294^{* \star *} \\
(0.0388)\end{array}$ & $\begin{array}{l}0.297^{\star \star *} \\
(0.0387)\end{array}$ & $\begin{array}{l}0.297^{\star \star *} \\
(0.0387)\end{array}$ \\
\hline I & $\begin{array}{l}-0.0405 \\
(0.0617)\end{array}$ & $\begin{array}{l}-0.0595 \\
(0.0615)\end{array}$ & $\begin{array}{l}-0.0491 \\
(0.0615)\end{array}$ & $\begin{array}{l}-0.0461 \\
(0.0547)\end{array}$ & $\begin{array}{l}-0.0584 \\
(0.0546)\end{array}$ & $\begin{array}{l}-0.0517 \\
(0.0546)\end{array}$ \\
\hline gamma & $\begin{array}{l}-0.113^{* * *} \\
(0.0248)\end{array}$ & $\begin{array}{l}-0.106^{* * *} \\
(0.0246)\end{array}$ & $\begin{array}{l}-0.106^{* * *} \\
(0.0248)\end{array}$ & $\begin{array}{l}-0.135^{\star \star *} \\
(0.0199)\end{array}$ & $\begin{array}{l}-0.127^{\star * *} \\
(0.0199)\end{array}$ & $\begin{array}{l}-0.129^{* * *} \\
(0.0200)\end{array}$ \\
\hline phi & $\begin{array}{l}0.0563 \\
(0.0538)\end{array}$ & $\begin{array}{l}0.0625 \\
(0.0536)\end{array}$ & $\begin{array}{l}0.0599 \\
(0.0537)\end{array}$ & $\begin{array}{l}0.201^{\star \star \star} \\
(0.0462)\end{array}$ & $\begin{array}{l}0.205^{\star \star \star} \\
(0.0461)\end{array}$ & $\begin{array}{l}0.203^{\star * \star} \\
(0.0462)\end{array}$ \\
\hline freedom & $\begin{array}{l}0.595^{* * *} \\
(0.0455)\end{array}$ & $\begin{array}{l}0.595^{\star * *} \\
(0.0451)\end{array}$ & $\begin{array}{l}0.598^{* * *} \\
(0.0453)\end{array}$ & $\begin{array}{l}0.759^{* * *} \\
(0.0400)\end{array}$ & $\begin{array}{l}0.762^{* * *} \\
(0.0397)\end{array}$ & $\begin{array}{l}0.763^{\star * *} \\
(0.0398)\end{array}$ \\
\hline wg & $\begin{array}{l}0.418 \\
(0.683)\end{array}$ & $\begin{array}{l}0.234 \\
(0.687)\end{array}$ & $\begin{array}{l}0.359 \\
(0.682)\end{array}$ & $\begin{array}{l}0.0868 \\
(0.639)\end{array}$ & $\begin{array}{l}-0.0186 \\
(0.650)\end{array}$ & $\begin{array}{l}0.0434 \\
(0.642)\end{array}$ \\
\hline ws & $\begin{array}{l}-115.7^{* * \star} \\
(24.74)\end{array}$ & $\begin{array}{l}-116.0^{* * *} \\
(24.69)\end{array}$ & $\begin{array}{l}-116.2^{* * *} \\
(24.68)\end{array}$ & $\begin{array}{l}-122.6^{* \star *} \\
(22.87)\end{array}$ & $\begin{array}{l}-121.3^{* * *} \\
(22.84)\end{array}$ & $\begin{array}{l}-121.8^{* * *} \\
(22.82)\end{array}$ \\
\hline wk & $\begin{array}{l}0.767 \\
(3.182)\end{array}$ & $\begin{array}{l}-0.129 \\
(3.147)\end{array}$ & $\begin{array}{l}0.102 \\
(3.224)\end{array}$ & $\begin{array}{l}4.427 \\
(2.494)\end{array}$ & $\begin{array}{l}4.399 \\
(2.551)\end{array}$ & $\begin{array}{l}4.155 \\
(2.559)\end{array}$ \\
\hline wh & $\begin{array}{l}1.101 \\
(0.700)\end{array}$ & $\begin{array}{l}1.011 \\
(0.698)\end{array}$ & $\begin{array}{l}1.075 \\
(0.699)\end{array}$ & $\begin{array}{l}-1.198^{* *} \\
(0.427)\end{array}$ & $\begin{array}{l}-1.223^{* *} \\
(0.426)\end{array}$ & $\begin{array}{l}-1.194^{* *} \\
(0.426)\end{array}$ \\
\hline wl & $\begin{array}{l}0.504 \\
(0.429)\end{array}$ & $\begin{array}{l}0.427 \\
(0.423)\end{array}$ & $\begin{array}{l}0.466 \\
(0.426)\end{array}$ & $\begin{array}{l}0.209 \\
(0.294)\end{array}$ & $\begin{array}{l}0.132 \\
(0.289)\end{array}$ & $\begin{array}{l}0.176 \\
(0.291)\end{array}$ \\
\hline wgamma & $\begin{array}{l}-0.0948 \\
(0.123)\end{array}$ & $\begin{array}{l}-0.0577 \\
(0.124)\end{array}$ & $\begin{array}{l}-0.0690 \\
(0.125)\end{array}$ & $\begin{array}{l}-0.234^{*} \\
(0.0972)\end{array}$ & $\begin{array}{l}-0.230^{*} \\
(0.101)\end{array}$ & $\begin{array}{l}-0.223^{*} \\
(0.100)\end{array}$ \\
\hline wphi & $\begin{array}{l}-0.660 \\
(0.516)\end{array}$ & $\begin{array}{l}-0.705 \\
(0.514)\end{array}$ & $\begin{array}{l}-0.669 \\
(0.515)\end{array}$ & $\begin{array}{l}0.225 \\
(0.235)\end{array}$ & $\begin{array}{l}0.191 \\
(0.238)\end{array}$ & $\begin{array}{l}0.206 \\
(0.236)\end{array}$ \\
\hline wfreedom & $\begin{array}{l}2.403 \\
(1.678)\end{array}$ & $\begin{array}{l}2.569 \\
(1.644)\end{array}$ & $\begin{array}{l}2.492 \\
(1.662)\end{array}$ & $\begin{array}{l}-1.601 \\
(1.302)\end{array}$ & $\begin{array}{l}-1.403 \\
(1.290)\end{array}$ & $\begin{array}{l}-1.490 \\
(1.296)\end{array}$ \\
\hline $\mathrm{fta}$ & $\begin{array}{l}0.458^{* * *} \\
(0.135)\end{array}$ & $\begin{array}{l}0.484^{* * *} \\
(0.135)\end{array}$ & $\begin{array}{l}0.470^{\star * *} \\
(0.135)\end{array}$ & $\begin{array}{l}0.312^{* *} \\
(0.119)\end{array}$ & $\begin{array}{l}0.329^{\star *} \\
(0.119)\end{array}$ & $\begin{array}{l}0.319^{* *} \\
(0.119)\end{array}$ \\
\hline wfta & $\begin{array}{l}1.858 \\
(4.999)\end{array}$ & $\begin{array}{l}3.142 \\
(4.992)\end{array}$ & $\begin{array}{l}2.658 \\
(4.992)\end{array}$ & $\begin{array}{l}6.573 \\
(3.885)\end{array}$ & $\begin{array}{l}7.252 \\
(3.877)\end{array}$ & $\begin{array}{l}6.976 \\
(3.879)\end{array}$ \\
\hline politics & $\begin{array}{l}0.00531^{* * *} \\
(0.000798)\end{array}$ & $\begin{array}{l}0.00736^{\star * *} \\
(0.000942)\end{array}$ & $\begin{array}{l}0.00333^{* * *} \\
(0.000447)\end{array}$ & $\begin{array}{l}0.00445^{\star \star *} \\
(0.000724)\end{array}$ & $\begin{array}{l}0.00642^{* * *} \\
(0.000890)\end{array}$ & $0.00283^{* * *}$ \\
\hline$(0.000412)$ & & & & & & \\
\hline wpolitics & $\begin{array}{l}0.00907 \\
(0.0115)\end{array}$ & $\begin{array}{l}0.0174 \\
(0.0163)\end{array}$ & $\begin{array}{l}0.00653 \\
(0.00714)\end{array}$ & $\begin{array}{l}0.0108 \\
(0.00895)\end{array}$ & $\begin{array}{l}0.0126 \\
(0.0133)\end{array}$ & $\begin{array}{l}0.00653 \\
(0.00568)\end{array}$ \\
\hline _cons & $\begin{array}{l}-48.90^{* *} \\
(17.25)\end{array}$ & $\begin{array}{l}-43.14^{*} \\
(17.57)\end{array}$ & $\begin{array}{l}-46.07^{* *} \\
(17.24)\end{array}$ & $\begin{array}{l}-11.95 \\
(14.66)\end{array}$ & $\begin{array}{l}-8.273 \\
(14.79)\end{array}$ & $\begin{array}{l}-10.24 \\
(14.70)\end{array}$ \\
\hline $\mathrm{N}$ & 2026 & 2026 & 2026 & 2602 & 2602 & 2602 \\
\hline
\end{tabular}


No. 378, 2009

Table A3 Political distance and FDI: country-pair fixed effects

\begin{tabular}{|c|c|c|c|c|}
\hline & $\begin{array}{l}\text { (1) } \\
\text { flows }\end{array}$ & $\begin{array}{l}(2) \\
\text { stocks stocks }\end{array}$ & $\begin{array}{l}\text { (3) } \\
\text { flows }\end{array}$ & $\begin{array}{l}\text { With time lag } \\
\text { (4) } \\
\text { stocks }\end{array}$ \\
\hline \multicolumn{5}{|l|}{ distance } \\
\hline$g$ & $\begin{array}{l}1.986^{*} \\
(0.894)\end{array}$ & $\begin{array}{l}2.097^{\star * *} \\
(0.509)\end{array}$ & $\begin{array}{l}2.238^{*} \\
(0.879)\end{array}$ & $\begin{array}{l}2.362^{\star \star *} \\
(0.500)\end{array}$ \\
\hline $\mathrm{s}$ & $\begin{array}{l}4.000 \\
(2.290)\end{array}$ & $\begin{array}{l}3.017^{*} \\
(1.338)\end{array}$ & $\begin{array}{l}5.147^{*} \\
(2.261)\end{array}$ & $\begin{array}{l}3.588^{\star \star} \\
(1.322)\end{array}$ \\
\hline k & $\begin{array}{l}-7.824^{\star} \\
(3.182)\end{array}$ & $\begin{array}{l}-7.409^{\star * \star} \\
(1.631)\end{array}$ & $\begin{array}{l}-8.595^{\star *} \\
(3.105)\end{array}$ & $\begin{array}{l}-7.456^{* * *} \\
(1.601)\end{array}$ \\
\hline h & $\begin{array}{l}0.129 \\
(0.0938)\end{array}$ & $\begin{array}{l}0.206^{\star * \star} \\
(0.0540)\end{array}$ & $\begin{array}{l}0.168 \\
(0.0973)\end{array}$ & $\begin{array}{l}0.188^{\star \star \star} \\
(0.0555)\end{array}$ \\
\hline I & $\begin{array}{l}1.193^{* * *} \\
(0.321)\end{array}$ & $\begin{array}{l}1.527^{* * *} \\
(0.198)\end{array}$ & $\begin{array}{l}1.183^{\star \star \star} \\
(0.345)\end{array}$ & $\begin{array}{l}1.481^{* \star *} \\
(0.210)\end{array}$ \\
\hline gamma & $\begin{array}{l}0.245^{*} \\
(0.112)\end{array}$ & $\begin{array}{l}0.242^{* * *} \\
(0.0577)\end{array}$ & $\begin{array}{l}0.274^{*} \\
(0.109)\end{array}$ & $\begin{array}{l}0.245^{\star \star *} \\
(0.0567)\end{array}$ \\
\hline phi & $\begin{array}{l}0.00933 \\
(0.0985)\end{array}$ & $\begin{array}{l}0.00794 \\
(0.0590)\end{array}$ & $\begin{array}{l}0.0379 \\
(0.0981)\end{array}$ & $\begin{array}{l}0.0129 \\
(0.0598)\end{array}$ \\
\hline freedom & $\begin{array}{l}0.305^{* * *} \\
(0.0633)\end{array}$ & $\begin{array}{l}0.336^{* * *} \\
(0.0367)\end{array}$ & $\begin{array}{l}0.294^{\star \star \star} \\
(0.0619)\end{array}$ & $\begin{array}{l}0.300^{* \star *} \\
(0.0360)\end{array}$ \\
\hline wg & $\begin{array}{l}-0.198 \\
(0.497)\end{array}$ & $\begin{array}{l}-0.237 \\
(0.316)\end{array}$ & $\begin{array}{l}-0.306 \\
(0.497)\end{array}$ & $\begin{array}{l}-0.189 \\
(0.316)\end{array}$ \\
\hline ws & $\begin{array}{l}-95.65^{* *} \\
(34.56)\end{array}$ & $\begin{array}{l}-17.98 \\
(19.03)\end{array}$ & $\begin{array}{l}-92.00^{* *} \\
(34.23)\end{array}$ & $\begin{array}{l}-19.55 \\
(18.97)\end{array}$ \\
\hline wk & $\begin{array}{l}3.766 \\
(2.446)\end{array}$ & $\begin{array}{l}3.458^{* *} \\
(1.247)\end{array}$ & $\begin{array}{l}4.259 \\
(2.469)\end{array}$ & $\begin{array}{l}3.524^{\star \star} \\
(1.264)\end{array}$ \\
\hline wh & $\begin{array}{l}0.159 \\
(0.535)\end{array}$ & $\begin{array}{l}-0.411 \\
(0.211)\end{array}$ & $\begin{array}{l}0.0707 \\
(0.535)\end{array}$ & $\begin{array}{l}-0.619^{* *} \\
(0.216)\end{array}$ \\
\hline wl & $\begin{array}{l}0.356 \\
(0.324)\end{array}$ & $\begin{array}{l}0.439^{* *} \\
(0.137)\end{array}$ & $\begin{array}{l}0.345 \\
(0.325)\end{array}$ & $\begin{array}{l}0.451^{* *} \\
(0.138)\end{array}$ \\
\hline wgamma & $\begin{array}{l}-0.158 \\
(0.0919)\end{array}$ & $\begin{array}{l}-0.128^{* *} \\
(0.0475)\end{array}$ & $\begin{array}{l}-0.174 \\
(0.0924)\end{array}$ & $\begin{array}{l}-0.131^{* *} \\
(0.0478)\end{array}$ \\
\hline wphi & $\begin{array}{l}-0.0815 \\
(0.391)\end{array}$ & $\begin{array}{l}-0.0778 \\
(0.113)\end{array}$ & $\begin{array}{l}-0.0682 \\
(0.391)\end{array}$ & $\begin{array}{l}0.00132 \\
(0.114)\end{array}$ \\
\hline wfreedom & $\begin{array}{l}1.674 \\
(1.389)\end{array}$ & $\begin{array}{l}-0.296 \\
(0.656)\end{array}$ & $\begin{array}{l}2.712 \\
(1.385)\end{array}$ & $\begin{array}{l}-0.291 \\
(0.658)\end{array}$ \\
\hline $\mathrm{fta}$ & $\begin{array}{l}0.468^{*} \\
(0.182)\end{array}$ & $\begin{array}{l}0.408^{* * *} \\
(0.110)\end{array}$ & $\begin{array}{l}0.434^{*} \\
(0.183)\end{array}$ & $\begin{array}{l}0.433^{\star * *} \\
(0.111)\end{array}$ \\
\hline wfta & $\begin{array}{l}4.315 \\
(4.556)\end{array}$ & $\begin{array}{l}1.929 \\
(2.197)\end{array}$ & $\begin{array}{l}2.777 \\
(4.588)\end{array}$ & $\begin{array}{l}1.676 \\
(2.212)\end{array}$ \\
\hline politics & $\begin{array}{l}0.000705 \\
(0.000802)\end{array}$ & $\begin{array}{l}0.000534 \\
(0.000492)\end{array}$ & $\begin{array}{l}-0.000289 \\
(0.000328)\end{array}$ & $\begin{array}{l}-0.000270 \\
(0.000209)\end{array}$ \\
\hline wpolitics & $\begin{array}{l}-0.00333 \\
(0.00814)\end{array}$ & $\begin{array}{l}0.00169 \\
(0.00414)\end{array}$ & $\begin{array}{l}-0.00490 \\
(0.00811)\end{array}$ & $\begin{array}{l}0.00357 \\
(0.00415)\end{array}$ \\
\hline _cons & $\begin{array}{l}-46.81 \\
(29.54)\end{array}$ & $\begin{array}{l}-47.67^{\star *} \\
(17.55)\end{array}$ & $\begin{array}{l}-56.88 \\
(29.27)\end{array}$ & $\begin{array}{l}-56.07^{\star \star} \\
(17.38)\end{array}$ \\
\hline $\mathrm{N}$ & 2026 & 2602 & 1943 & 2478 \\
\hline
\end{tabular}




\section{Notes}

$1 \quad$ Switzerland ranks higher than the Netherlands but is not used as the coverage of recipient countries was not as wide ranging as the Dutch FDI.

2 http://www.freetheworld.com/

3 http://www.icgg.org/corruption.index.html

4 http://info.worldbank.org/governance/wgi/index.asp

$5 \quad$ National People's Congress (1986), Promulgated by Order No. 39 of the President of the People's Republic of China and effective as of April 12, 1986.

6 Bilateral political distance is included for all source and host country pairs in the earlier analysis and as described in the Data Annex except for Germany as a source due to data limitations in the original dataset.

\section{References}

Anderson, J.E. and van Wincoop, E., 2004. 'Trade Costs', Journal of Economic Literature $42(3): 691-751$.

Arellano, M. and Bond, S., 1991. 'Some tests of specification for panel data', Review of Economic Studies 58.

Armstrong, S. P., 2007. 'Commercial Self-interest a Politic Course', The Australian

Financial Review, 11 April 2007, p. 63.

Baldwin, R. E., 1994. Towards and Integrated Europe, Centre for Economic Policy Research, London.

—, Francois, J. and Portes, R., 1997. 'The costs and benefits of eastern enlargement', Economic Policy, 24:125-176.

Baltagi, Badi, Peter Egger and Michael Pfaffermayr, 2007, 'Estimating models of complex FDI: Are there third-country effects?', Journal of Econometrics 140(1): 260-281.

Beckerman, W. 1956. 'Distance and the Pattern of Inter-European Trade', The Review of Economics and Statistics, 38(1): 31-40.

Blonigen, Bruce A. 2005, 'A Review of the Empirical Literature on FDI Determinants' (May 2005). NBER Working Paper No. 11299.

-. and Ronald B. Davies, 2000. 'The effects of bilateral tax treaties on U.S. FDI activity', NBER Working Paper No. 7929.

—, Ronald Davies, Glan Waddell and Helen Naughton, 2004. 'FDI in Space: spatial autoregressive relationships in foreign direct investment', NBER Working Paper No. 10939.

Brenton, Paul and Francesca Di Mauro, 1999 'Economic integration and FDI: an empirical analysis of foreign investment in the EU and in Central and Eastern Europe', Empirica, 26:95-121.

Carr, D.L., Markusen, J.R., and Maskus, K.E., 2001. 'Estimating the Knowledge-Capital model of the Multinational Enterprise', American Economic Review 91:693-708.

China National People's Congress, 1986. Law of the People's Republic of China on Foreign-Capital Enterprises, National People's Congress.

Davies, Ronald B., 2008. 'Hunting High and Low for Vertical FDI', Review of International Economics, Blackwell Publishing 16(2):250-267.

Dee, Philippa, 2007. 'Multinational Corporations and Pacific Regionalism', Pacific Economic Papers No. 358.

Drysdale, P. and Garnaut, R., 1982. 'Trade Intensities and the Analysis of Bilateral Trade Flows in a Many-Country World: A Survey', Hitotsubashi Journal of Economics 22(2):62-84. 
Drysdale, P. and L. Song, 2002. China's Entry to the WTO: Strategic Issues and Quantitative Assessments, Routledge, London.

Egger, Peter, 'An Econometric View on the Estimation of Gravity Models and the Calculation of Trade Potentials', The World Economy 25 (2), 2002:297-312.

—, 2008, 'Bilateral FDI Potentials for Austria', FIW Research Report No. 11, June.

- and Michael Pfaffermayr, 2004. 'Distance, trade and FDI: a Hausman-Taylor SUR approach' Journal of Applied Econometrics 19(2):227-246.

Eichengreen, Barry and Hui Tong, 2005 'Is China's FDI Coming at the Expense of Other Countries?’, NBER Working Paper No. 11335.

Erramilli M. K. and D'Souza, D. E., 1995. 'Uncertainty and foreign direct investment: The role of moderators', International Marketing Review 12(3):47-60

Fukuda, Kazuo John, 1998. Japan and China: The Meeting of Asia's Economic Giants, Haworth Press.

Ghemawat, Pankaj, 2007. Redefining Global Strategy: Crossing Borders in a World Where Differences Still Matter, Harvard Business School Press, Massachusetts.

Goldstein, J. S., 1992. 'A conflict-cooperation scale for WEIS event data', Journal of Conflict Resolution, 36:369-385.

Grossman, G.M., Helpman, E. and Szeidl, A., 2006. 'Optimal integration strategies for the multinational firm', Journal of International Economics 70:216-238.

Guiso, Luigi, Paola Sapienza and Luigi Zingales, 2004. 'Cultural Biases in Economic. Exchange', NBER Working Paper No. 11005.

Hanson, Gordon, and Robert Feenstra, 2001. 'Intermediaries in Entrepot Trade: Hong Kong Re-Exports of Chinese Goods', NBER Working Paper No. 8088.

Head, Keith and Thierry Mayer, 2004. 'Market Potential and the Location of Japanese Investment in the European Union', Review of Economics and Statistics 86(4):959-972.

Helpman, E., 1984. 'A simple theory of international trade with multinational corporations', Journal of Political Economy 92:451-472.

-, Melitz, M. and Yeaple, S.R., 2004. 'Export versus FDI with heterogeneous firms', American Economic Review 94:300-316.

Hymer, S. H. 1960 (1976). The international operations of national firms: A study of direct foreign investment,.Cambridge, MA: MIT Press.

Japan Bank for International Cooperation Institute (JBICI) Review, various years, http://www. jbic.go.jp/english/research/report/review/index.php.

King, Gary, 2003. '10 Million International Dyadic Events', hdl:1902.1/FYXLAWZRIA UNF:3: um06qkr/ltAwpS4roUqAiw== Murray Research Archive [Distributor] http://gking. harvard.edu/homepage.html

- and W. Lowe, 2003. 'An Automated Information Extraction Tool For International Conflict Data with Performance as Good as Human Coders: A Rare Events Evaluation Design', International Organization 57(3): 617-642.

Knickerbocker, F.T., 1973. Oligopolistic Reaction and the Multinational Enterprise, Harvard University Press: Cambridge, MA.

Lardy, Nicholas, 2002. Integrating China into the Global Economy, Brookings Institution Press, Washington DC.

Leamer, Edward, 1984. Sources of international comparative advantage, MIT Press, Cambridge.

Linnemann, H., 1966. An Econometric Study of International Trade Flows, North Holland Publishing Company, Amsterdam.

Luo, Yadong, 2001. Strategy, Structure and Performance of MNCs in China, Greenwood Publishing Group, Santa Barbara, US. 
Mansfield, E. and B. Pollins, 2003. Economic Interdependence and International Conflict: New Perspectives on an Enduring Debate (eds.), University of Michigan Press, Michigan.

Markusen, J.R., 1984. 'Multinationals, multi-plant economies, and the gains from trade', Journal of International Economics 16:205-226.

- , 2002. Multinational Firms and the Theory of International Trade, Cambridge: MIT Press.

— and Maskus, Keith E, 2002. 'Discriminating among Alternative Theories of the Multinational Enterprise', Review of International Economics, Blackwell Publishing 10(4):694-707.

Polachek, S. W., 1980. 'Conflict and trade', Journal of Conflict Resolution, 24:55-78.

—, 1997. 'Why Democracies Cooperate More and Fight Less: The Relationship Between International Trade and Cooperation', Review of International Economics, 5:295-309.

Pollins, B., 1989a. 'Conflict, Cooperation, and Commerce', American Journal of Political Science, 33:737-61.

—, 1989b. 'Does Trade Still Follow the Flag?' American Political Science

Review, 83:465-80.

Razin, Assaf, Mody Ashoka and Efraim Sadka, 2002 'The role of information in driving FDI: theory and evidence', NBER Working Paper No. 9255.

Reuveny, R. and H. Kang, 2003. 'A simultaneous-equations model of trade, conflict, and cooperation', Review of International Economics, 11:279-95.

Yeaple, S.R., 2003. 'The complex integration strategies of multinational firms and cross-country dependencies in the structure of foreign direct investment', Journal of International Economics 60:293-314.

* Acknowledgements: This study benefitted greatly from comments and suggestions by Peter Drysdale, Ligang Song, Jane Golley and Alberto Posso. I am grateful to Hannah Beven who helped with data extraction and especially grateful to Philippa Dee for her advice and sharing data from her earlier study. Any errors are mine alone. This paper was the runner-up in the Australia-Japan Research Centre's 2008 Crawford Award. 


\section{Previous Asia Pacific Economic Papers}

377 Expansion Abroad and Jobs at Home: Evidence from Japanese Multinational Enterprises Nobuaki Yamashita and Kyoji Fukao, 2008

376 Should Australia Encourage Developing Countries to Adopt Competition Laws? Henry Ergas, 2008

375 Will New Trends in Foreign Direct Investment Change the Structure of Intra-industry Trade between China and Japan?

Tao Tao, 2008

374 Competition Policy in ASEAN: Case studies Johannah Branson, 2008

373 Can the New Antimonopoly Act Change the Japanese Business Community? The 2005 Amendment to Antimonopoly Act and Corporate Compliance. Kazukiyo Onishi, 2008

372 Immunising future trade against protectionists: preventing the emergence of more sensitive sectors Andrew Elek, 2008

371 Tax law asymmetries and income shifting: evidence from Japanese Capital KEIRETSU Kazuki Onji and David Vera, 2008

370 The response of firms to eligibility thresholds: evidence from the Japanese value-added tax Kazuki Onji, 2008

369 China and East Asian Energy: Prospects and Issues Vol. 1 \& 11

Peter Drysdale, Kejun Jiang and Dominic Meagher, 2008

368 Measuring trade and trade potential Shiro Armstrong, 2007

367 APEC and infectious disease: meeting the challenge Joel Gilbourd, 2007

366 The flow of funds through a government - A case study on Japan Jun Ikeda, 2007

365 The puzzle of small farming in Japan Yoshibisa Godo, 2007

364 How should one evaluate fiscal conditions? A study based on the comparison between Japan and Australia Jun Ikeda, 2007

363 Political institutions and distributive politics in Japan: getting along with the opposition Tusaku Horiuchi, 2007

362 Negotiating the Australia-Japan basic treaty of friendship and cooperation: reflections and afterthoughts

Garry Woodard, Moreen Dee and Max Suich, 2007

361 China and East Asian energy: prospects and issues Vol. 1 Peter Drysdale, Kejun Jiang and Dominic Meagher, 2007

360 Agriculture and political reform in Japan: the Koizumi legacy Aurelia George Mulgan, 2006

359 Nothing new in the (north) east? Interpreting the rhetoric and reality of Japanese corporate governance

Luke Nottage, 2006

358 Multinational corporations and Pacific regionalism Philippa Dee, 2006

357 Reliability of structural shocks estimates from a bivariate SVAR model: the case of Southeast Asian countries 
Asia Pacific Economic Papers

\section{Previous Asia Pacific Economic Papers}

373 Can the New Antimonopoly Act Change the Japanese Business Community? The 2005 Amendment to Antimonopoly Act and Corporate Compliance.

Kazukiyo Onishi, 2008

372 Immunising future trade against protectionists: preventing the emergence of more sensitive sectors Andrew Elek, 2008

371 Tax law asymmetries and income shifting: evidence from Japanese Capital KEIRETSU Kazuki Onji and David Vera, 2008

370 The response of firms to eligibility thresholds: evidence from the Japanese value-added tax Kazuki Onji, 2008

369 China and East Asian Energy: Prospects and Issues Vol. 1 \& 11 Peter Drysdale, Kejun Jiang and Dominic Meagher, 2008

368 Measuring trade and trade potential Shiro Armstrong, 2007

367 APEC and infectious disease: meeting the challenge Joel Gilbourd, 2007

Annual subscription rate for up to twelve issues:

Individuals A $\$ 65.00$ (includes GST) A $\$ 60$ (overseas)

Institutions A $\$ 10.00$ (includes GST) A \$100 (overseas)

\section{Cost for single issues:}

A $\$ 16.50$ (includes GST) A \$15.00 (overseas)

A $\$ 10.00$ (Students)

No postage required within Australia

\section{Available from:}

Centre Administrator

Australia-Japan Research Centre

Crawford School of Economics and Management

ANU College of Asia and the Pacific

The Australian National University

Canberra ACT 0200, Australia

Facsimile: (61 2) 61250767

Telephone: (61 2) 61253780

Email: ajrc@anu.edu.au

URL: http:/www.crawford.anu.edu.au 